\title{
Database of 478 allometric equations to estimate biomass for Mexican trees and forests
}

\author{
Fabiola Rojas-García • Bernardus H. J. De Jong • \\ Pablo Martínez-Zurimendí • Fernando Paz-Pellat
}

Received: 14 March 2014 / Accepted: 5 January 2015 / Published online: 30 January 2015

(C) INRA and Springer-Verlag France 2015

\begin{abstract}
- Key message We present a comprehensive database of 478 allometric equations to estimate biomass of trees and other life forms in Mexican forest and scrubland ecosystems.

- Context Accurate estimation of standing biomass in forests is a prerequisite for any approach to carbon storage and a number of additional applications.
\end{abstract}

Handling Editor: Laurent Saint-Andre

Contribution of the co-authors Fabiola Rojas-García: compilation of allometric equation database and metadata; writing of methodology and parts of the results and discussion; and elaboration of Fig. 2

Bernardus H.J. de Jong: database analysis and writing of introduction, results and discussion, and elaboration of Tables and Fig. 1

Pablo Martínez-Zurimendí: compilation of a part of the database and contributions to the discussion section

Fernando Paz-Pellat: collection of equations for the database and database structure

F. Rojas-García

Programa Mexicano del Carbono, Chiconautla 8 Col. Lomas de

Cristo, C.P. 56230 Texcoco, Estado de México, Mexico

B. H. J. De Jong $(\square)$

El Colegio de la Frontera Sur, Unidad Campeche. Av. Rancho

Polígono 2-A, Col. Ciudad Industrial, C.P. 24500 Lerma Campeche, Campeche, Mexico

e-mail: bjong@ecosur.mx

P. Martínez-Zurimendí

El Colegio de la Frontera Sur, Unidad Villahermosa.

Carr. Villahermosa-Reforma km 15.5, Ranchería Guineo $2^{\mathrm{a}}$ sección, CP 86280 Villahermosa, Tabasco, Mexico

F. Paz-Pellat

Colegio de Postgraduados, Campus Montecillo,

Carr. México-Texcoco km. 36.5, Montecillo, C.P. 56230 Texcoco,

Estado de México, Mexico
- Aims To provide a comprehensive database with allometric equations applicable to a large number of tree and shrub species of Mexico.

- Methods An intensive literature search was carried out to pull together all publications related to allometric equations in the libraries of the most important forest research institutes across Mexico and the neighboring countries.

- Results A total of 478 equations were compiled. Four hundred fourteen equations included a detailed analysis of all compartments of the trees; 7 equations applied to shrubs, 15 to bamboos, and 2 to palms. The collected equations are applicable to a wide variety of forest ecosystems in Mexico ranging from desert scrublands in the North to lowland evergreen rainforests in the South. The attached database of allometric equations is possibly the most extensive compilation of equations currently available for Mexico.

- Conclusion The database covers almost $100 \%$ of the individuals recorded in the National Forest Inventory.

Keywords Biomass $\cdot$ Database $\cdot$ Allometric equations

\section{Introduction}

The accurate estimation of forest biomass has been crucial for many applications: the commercial use of wood produced in studies of forest production (Morgan and Moss 1985), correlation of forest biomass with stand density (Baskerville 1965), in studies comparing biomass and production for individual tree species (Pastor and Bockheim 1981), in studies on forest fuel estimation (Agee 1983), and recently, to determine the role of forest biomass in the global carbon (C) cycle (Bombelli et al. 2009). Allometric equations are the most commonly used tool to estimate volume or biomass from forest inventory data (e.g., species, tree diameter, and height). Despite their importance, existing 
equations are often scattered over forest research centers, forest administrations, logging companies, and libraries (FAO 2013). The need for accurate equations is driven by the increasing need for information of biomass in forests for climate policy definition and formulation (cf. REDD+), which requires reliable estimations of carbon in forest ecosystems (e.g., Brown 2001; Wirth et al. 2003; Joosten et al. 2004; Rosenbaum et al. 2004). The estimation of the total above-ground biomass (TAGB) with an accuracy that allows the modeling of increments or decrements in carbon stored in the forest over relatively short periods of time (210 years) is increasingly required (Basuki et al. 2009). Under the United Nations Framework Convention on Climate Change (UNFCCC) and the 5-year forest resources assessments of FAO, countries need to report regularly the state of their forest resources, biomass densities, and carbon stocks and the results of emerging mechanisms such as Reducing Emissions from Deforestation in Developing Countries (REDD) that will require temporally and spatially fine-grained assessments of carbon stocks (UNFCCC 2008).

Many models are developed for single tree species with different levels of uncertainty (Fehrmann and Kleinn 2006; Návar 2009a). There have also been various attempts to derive more flexible models, applicable for many species or for specific ecosystems, by meta-analysis of published equations to generate an operational database to be used in compliance with the Kyoto protocol (Zianis and Mencuccini 2004; Chave et al. 2005; Zianis et al. 2005; Návar 2010a, b). These models may be adequate to estimate biomass at a national or regional scale, but these may not correctly reflect the tree biomass in a specific area or project (Segura and Kanninen 2005).

The most accurate method for the estimation of biomass is through cutting of trees and weighing of their parts. This destructive method is often used to validate other less intensive and costly methods such as the estimation of carbon stock using nondestructive in-situ measurements and remote sensing (Clark et al. 2001; Wang et al. 2003). Allometric equations developed on the basis of sparse measurements from destructive sampling of trees along a range of tree sizes are statistically related to more easily collected biophysical properties of trees, such as diameter at breast height, wood density, and total height (Basuki et al. 2009) by means of allometric equations. Diameter at breast height is the most commonly used parameter in forest inventories, whereas height normally is measured in a subset of trees to develop diameter-height curves (Bravo et al. 2007).

In Mexico, there have been attempts to review and compile the available equations. Návar (2009a) did a review of equations developed to estimate biomass components of trees and shrubs of different forest communities in arid, semi-arid, subtropical, tropical, and temperate Latin-American ecosystems. De Jong et al. (2009) compiled a database of allometric equations for tree species or genera and equations at the level of ecosystems to estimate the biomass of the trees measured in the national forest inventory This paper is a continuation of the previous efforts to present an overview of the most accessible equations available in the literature to estimate biomass and carbon of Mexican tree species and forests. Henry et al. (2013) stressed the importance of such compilations of equations and pointed out that these should be made available in easy to use databases.

In this study, allometric equations developed for woody species growing in Mexico are compiled, and a database was developed to be used for forest above-ground biomass estimation (stem plus branches and foliage) at the level of individual tree species, species groups, genera, and ecosystems of Mexican forests. These can either be used to estimate biomass in certain forest stands or for national estimations of biomass. We tested the equation data base, to see to what extent it covers the total number of individuals registered in the national forest inventory, carried out between 2004 and 2007.

\section{Methods}

An extensive revision of the literature was carried out to locate publications with allometric equations to estimate biomass in woody plants of Mexico. In the case of conventional publications (scientific papers and indexed peerreviewed books), publicly available search engines were used such as Science Direct, Google Academic, Redalyc, and Scopus. Additionally, an extensive search was carried out to locate the so-called grey publications such as thesis, reports, and extensive summaries published in the proceedings of scientific meetings. Physical or virtual visits to academic institutions were carried out to locate these types of publications. In both cases, a series of keywords with logical operators were used to select the relevant literature: biomass, above-ground biomass, above-ground forest biomass, total tree weight, carbon content of biomass, carbon sequestration, harvestable volume, expansion factors for trees, biomass expansion factor, biomass density, carbon density, allometric equations, allometric equations to estimate biomass, and regression models. Once a document with an allometric equation was located, the relevant information was extracted and systematically put into a database with various fields: species, genus, life form, type of vegetation, size of the plant, age of the vegetation, climatic 
characteristics, type of management, type of allometric equation, and their variables used, among others. More general equations were also put into the database recording the same information such as equations applicable for genera or groups of species, equations applicable for specific ecosystems, and generic type of equations. The equations are grouped according to life form and independent variables used to calculate biomass, type of allometric equation, forest type for which the equation is applicable, and the number of equations in each common plant family. To test the potential of the database, we estimated the number of individuals covered by a biomass equation that are recorded in the National Forest and Soil Inventory 2004-2009 (INFyS). The individuals of the INFyS that were determined at the level of species were taken into consideration (tree, shrub, bamboo, and palm).

The scientific names were analysed with the package Taxonstand version 1.0 (Cayuela et al. 2012) within the Rsoftware environment (R Development Core Team 2012) to correct the scientific names due to taxonomic revisions, orthographic corrections, and elimination of synonyms validating the names according to the latest revisions by taxonomic experts (The Plant List 2010).

We classified the species into the following three groups: (1) species for which the equation database contained an equation at the level of species, (2) species with an equation at the level of genus, and (3) species that are covered by an equation developed for a certain group of species or ecosystem. Once the name of the plants in the INFyS database was checked for consistency, the number of plant records, for which some type of equation was available, was counted.

\section{Results}

\subsection{Literature review}

The extensive search for literature included physical and virtual visits to a total of 42 national institutes of higher education and research and 4 foreign institutes. A total of 29 scientific journals were searched with a variety of search engines. A total of 225 documents were located, such as scientific papers, thesis, and extensive memories of scientific events. Each document was checked to evaluate its relevance for the database, as the search with keywords also detected papers, which used allometric equations developed by other authors. As such, a total of 80 documents were selected, from which all relevant data were extracted and inserted in the general database, so as to provide information on the species, the range of the independent variables and
Table 1 Number of equations for each life form and the component evaluated

\begin{tabular}{|c|c|c|c|c|c|c|}
\hline \multirow[b]{2}{*}{ Stock } & \multirow[b]{2}{*}{ Component } & \multicolumn{5}{|c|}{ Life form } \\
\hline & & Tree & Shrub & Palm & Bamboo & Total \\
\hline \multirow{6}{*}{$\begin{array}{l}\text { Above-ground } \\
\text { biomass }\end{array}$} & Branches & 11 & & & 3 & 14 \\
\hline & Foliage & 8 & & & 4 & 12 \\
\hline & $\begin{array}{l}\text { Leaves }+ \\
\quad \text { branches }\end{array}$ & 35 & & & & 35 \\
\hline & Stem & 46 & & & 4 & 50 \\
\hline & Support roots & & & & & 1 \\
\hline & $\begin{array}{l}\text { Whole } \\
\text { individual }\end{array}$ & 293 & 47 & 2 & 4 & 346 \\
\hline $\begin{array}{l}\text { Belowground } \\
\text { biomass }\end{array}$ & Roots & 5 & 8 & & & 13 \\
\hline Carbon content & $\begin{array}{l}\text { Whole } \\
\text { individual }\end{array}$ & 15 & & & & 15 \\
\hline Total & & 414 & 47 & 2 & 15 & 478 \\
\hline
\end{tabular}

site-specific characteristics. Duplicate publications (thesis converted to scientific paper) were eliminated if these contained the same information, which resulted in a final list of 69 documents.

\subsection{Extracted information}

A total of 478 allometric equations were collected from the literature to estimate total biomass, carbon in biomass, aboveground biomass, or root biomass for trees (414), shrubs (47), bamboos (15), and palms (2; Table 1).

About 150 equations were specifically developed for one species, whereas 15 equations were developed at the level of genus, and 26 equations were applicable for a group of species or species within a certain ecosystem.

Most of the equations estimated total biomass, although some used an additive formula, summing separately estimated biomass of trunks, branches and leaves, or other parts. The most common variables used in the equations were diameter at breast height $(\mathrm{DBH}$, in 384 equations) and total height ( $\mathrm{TH}$, in 96 equations; Table 2).

Other variables used include diameter at other heights $(0.30$ in 49 equations, 0.10 in 15 equations, and basal diameter in 32 equations), basal area (BA, 19 eq.), crown diameter (DC, 1 eq.), crown height (HC, 3 eq.), trunk volume (Vol, 10 eq.), and stem basal perimeter (BP, 1 eq.; Table 2).

The non-linear equation was the most common type of model published (295 equations) followed by the 
Table 2 Number of equations according to life form and independent variables used in the equation

\begin{tabular}{|c|c|c|}
\hline Life form & Variables & Number of equations \\
\hline \multirow[t]{12}{*}{ Tree } & BA, TH & 17 \\
\hline & $\mathrm{D}_{0.30}, \mathrm{TH}$ & 4 \\
\hline & $\mathrm{D}_{0.30}$ & 3 \\
\hline & DBH,WD & 1 \\
\hline & DBH, TH, WD & 4 \\
\hline & $\mathrm{DBH}$ & 320 \\
\hline & $\mathrm{DBH}, \mathrm{TH}$ & 43 \\
\hline & $\mathrm{D}_{0.10}$ & 2 \\
\hline & $\mathrm{D}_{0.0}, \mathrm{TH}$ & 5 \\
\hline & $\mathrm{BP}$ & 1 \\
\hline & $\mathrm{RC} 1, \mathrm{RC} 2$ & 1 \\
\hline & Vol & 10 \\
\hline \multirow[t]{7}{*}{ Shrub } & $\mathrm{BA}, \mathrm{TH}$ & 2 \\
\hline & $\mathrm{DC}$ & 1 \\
\hline & $\mathrm{RC} 1, \mathrm{RC} 2, \mathrm{HC}$ & 3 \\
\hline & $\mathrm{D}_{0.10}$ & 13 \\
\hline & $\mathrm{D}_{0.0}$ & 9 \\
\hline & $\mathrm{D}_{0.0}, \mathrm{TH}$ & 18 \\
\hline & $\mathrm{TH}$ & 1 \\
\hline Bamboo & $\mathrm{DBH}$ & 15 \\
\hline Palm & $\mathrm{DBH}, \mathrm{TH}$ & 2 \\
\hline Total & & 478 \\
\hline
\end{tabular}

$B A$ basal area, $T H$ total height, $D_{0.30}$ diameter of the stem at $30 \mathrm{~cm}, D B H$ diameter at breast height $(1.30 \mathrm{~m}), W D$ wood density, $D_{0.10}$ diameter of the stem at $10 \mathrm{~cm}, D_{0.0}$ basal diameter of the stem, $B P$ basal perimeter of the stem, $R C 1, R C 2$ radii of two orthogonal diameters of the crown, $\mathrm{Vol}$ volume of the trunk with bark, $D C$ average diameter of the tree canopy, $H C$ height of the tree canopy

exponential type of equations (112 eq.), whereas 52 equations were polynomial, two linear and 17 equations had at least part of the variables expressed at a logarithmic scale (Table 3).

Table 3 Number of allometric equations according to equation type

\begin{tabular}{lc}
\hline Type of equation & Number of equations \\
\hline Linear equation & 2 \\
Polynomial equation & 52 \\
Exponential equation & 112 \\
Non-linear equation & 295 \\
Logarithmic equation & 17 \\
\hline
\end{tabular}

Table 4 Number of equations recorded according to type of forest

\begin{tabular}{|c|c|c|}
\hline Ecoregion & Forest type & $\begin{array}{l}\text { Number of } \\
\text { equations }\end{array}$ \\
\hline \multirow[t]{6}{*}{ Upland forests } & Cultivated forest & 41 \\
\hline & Conifer forest & 18 \\
\hline & Pine forest & 73 \\
\hline & Pine-oak forest & 78 \\
\hline & Oak forest & 6 \\
\hline & Cloud forest & 32 \\
\hline \multirow[t]{2}{*}{ Scrublands } & Scrubland & 59 \\
\hline & Submontane scrubland & 21 \\
\hline \multirow[t]{5}{*}{ Lowland forests } & Deciduous forest & 95 \\
\hline & Semi-deciduous forest & 25 \\
\hline & Semi-evergreen forest & 4 \\
\hline & Evergreen forest & 15 \\
\hline & Inundated forests (including mangroves) & 11 \\
\hline
\end{tabular}

Most of the equations were applicable for species belonging to seven upland forest types (228 equations), whereas 150 equations were found for five lowland forest types, whereas 80 equations are associated with two types of scrubland vegetation (Table 4).

Taking into consideration the taxonomic representation, the highest number of equations were developed for species belonging to the Pinaceae (mostly Pinus), which represents the family with the most important commercial species, followed by Fabacea and Fagaceae, also economically important

Table 5 Number of equations applicable to species within the most common Mexican plant families

\begin{tabular}{lc}
\hline Plant family & Number of equations \\
\hline Pinaceae & 132 \\
Fabaceae & 73 \\
Fagaceae & 50 \\
Euphorbiaceae & 15 \\
Poaceae & 15 \\
Asteraceae & 11 \\
Malvaceae & 11 \\
Burseraceae & 10 \\
Rutaceae & 10 \\
Remaining families (45) & 122 \\
Equations for species of more than one family & 29 \\
\hline
\end{tabular}


Table 6 Application of allometric equations for Pinus patula to data of trees recorded in the national forest inventory

\begin{tabular}{llllll}
\hline Allometric equation & State of Mexico & DAP minimum $(\mathrm{cm})$ & DAP maximum $(\mathrm{cm})$ & All records INFyS & INFyS records \\
\hline Pacheco 2011 & Oaxaca & 5.0 & 30.0 & $R^{2}=0.945$ & $R^{2}=0.947$ \\
Castellanos et al. 1996 & Puebla & 5.0 & 45.0 & $R^{2}=0.935$ & $R^{2}=0.943$ \\
Díaz 2005 & Tlaxcala & 6.7 & 64.1 & $R^{2}=0.894$ & $R^{2}=0.932$ \\
\hline
\end{tabular}

families; all together, these three families covered by about $50 \%$ of all equations (Table 5). Various Pinus species had more than one equation, developed in different geographic entities. (See Table 6.)

For Pinus patula, a total of 14 equations have been published; of which, seven estimate total above-ground biomass with varying range of diameters for which the equations are applicable. For example, Pacheco (2011) developed the equation in the state of Oaxaca for individuals with DBH between 5 and $30 \mathrm{~cm}$ Castellanos et al. (1996): in Puebla, with indidividuals with DBH between 5 and $45 \mathrm{~cm}$; and Díaz (2005) in Tlaxcala, with a range of DBH between 6.7 and $64.1 \mathrm{~cm}$.

Comparing the outcome of the three models, estimating the biomass of individuals registered in the national inventory, shows that they do not differ much even outside the range of diameters for which they were developed (Fig. 1).

The models were developed in 26 out of 32 federal states, with the highest numbers of equations in Durango

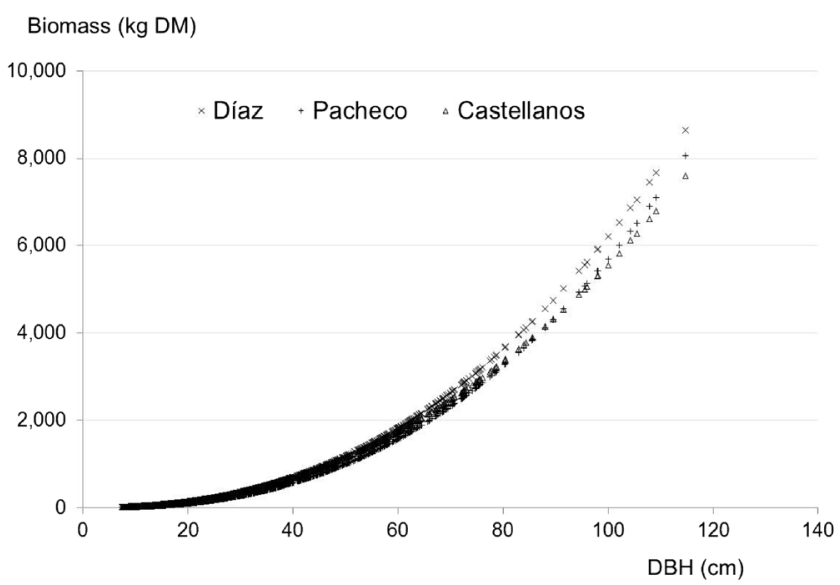

Fig. 1 Application of three published models of Pinus patula to all data of the species recorded in the national inventory Castellanos et al. 1996; Pacheco 2011; Díaz 2005 and Chihuahua; both are very important wood-producing states.

Some models were developed for species occurring in more than one state (Návar et al. 2004a, b; Návar 2009a, b; Návar 2010a, b). In the Appendix, we present all the equations of the database.

Most of the reports include some measures of confidence of the equation to replicate the results, such as the proportion of variance explained by the model, the difference between the estimator and the real value, or standard error.

\subsection{Potential use of the equations}

To test the extent to which the collected equations apply to the national forest inventory data, we compared the equation database with the 1,023,723 individuals recorded in the National Forest and Soil Inventory 2004-2009 (INFyS). The INFyS contain individuals belonging to 2623 species of 787 taxonomic genera. After the analysis

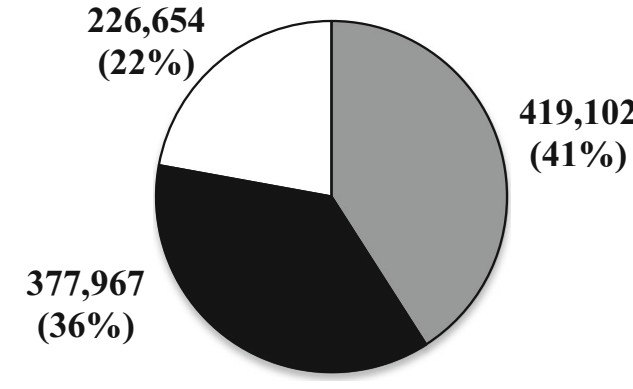

$\square$ Records with a species level equation

- Records with a genus level equation

$\square$ Records with an ecosystem level equation

Fig. 2 Number and percentage of woody species registered in the National Forest Inventory (2004-2007) that have an allometric equation that correspond to one particular species, to species groups, and to ecosystem type 
with Taxonstand, the inventory contained 2175 species of 708 genera.

A total of $41 \%$ of the individuals of the INFyS were covered by a specific equation, $36 \%$ by an equation developed for a genus, and the remaining $22 \%$ were almost completely covered by either a species group or ecosystem equation. Thus, almost $100 \%$ of the individuals of the INFyS are covered one or more nationally developed allometric equation to estimate the biomass (Fig. 2).

\section{Discussion}

The allometric models for woody plant species of Mexico cover a wide range of species and forest ecosystems, parameters used to relate biomass to tree structural variables, and type of regression. More than $40 \%$ of the individuals recorded in the INFyS 2004-2009 are covered by a species-specific allometric equation. Biomass can be estimated with equations that have been developed either for the same species, species belonging to the same genus or ecosystem, each with their specific level of uncertainty. Application of empirical equations outside the region from which they were developed or extrapolation of biomass estimated beyond the range of the independent variables could unpredictably increase uncertainty. If the equation is developed for smaller trees, applying it to trees much larger than the range increases substantially the uncertainty of the estimation (Brown 1997).

In order to reduce the uncertainty of the models in relation to applying these to trees outside the dimensions for which the model was developed or outside the ecological condition where the sampled trees occurred, or other factors that may create the uncertainty in the estimations, a sampling procedure needs to be designed to validate, simplify or adjust the available models, such as the small trees sampling scheme proposed by Zianis and Mencuccini (2004) or the non-sampling scheme methodology proposed by Návar (2010a, b), who applied the Central Limit Theorem for equations of neighboring tree species or genus. Bayesian analysis may also provide the means to circumvent such caveats, as well.

Due to the high diversity of tree species, it is not efficient to develop models for each species. Validating and improving models developed for certain ecosystems may be a viable solution, such as the incorporation of wood density as an independent variable (Urquiza-Haas et al. 2007; Chave et al. 2014).

Also, equations that use total height (TH) and $\mathrm{DBH}$ as independent variables are generally more widely applicable than equations with only DBH, as these may capture better the variation in the $\mathrm{DBH} / \mathrm{TH}$ ratio due to ecological conditions. Návar et al. (2013) found that other more complex variables such as tree slenderness (DBH/TH), tree cylindrical (VOL/ $\left.\left(\mathrm{DBH}^{2} \mathrm{TH}\right)\right)$ or a compound form factor $(\mathrm{DBH} / \mathrm{TH} * \mathrm{VOL} /$ $\left(\mathrm{DBH}^{2} \mathrm{TH}\right)$ ) explain much more above-ground variability than $\mathrm{H}$ alone, and avoid multicollinearity problems. Furthermore, height is often difficult to measure, particularly in dense tropical forests. Equally, if ecological conditions of the trees in the inventory are very different from the conditions where the equation was developed, the tree architecture may change substantially (Rykiel 1996; Oldeman 1990). Particularly in countries like Mexico where a high variety of ecological conditions and management practices may create a high variety in architectural structures of the trees of the same species, it is important to estimate the error associated with this variation. Other factors that may influence the distribution of biomass and as such the uncertainty in biomass estimations, are related to the openness or closeness of the canopy, where more biomass is allocated to branches in trees growing in open spaces, compared to the same species in closed canopies (see also Dietze et al. 2008). As such, the slenderness, cylindrical or composite form factors introduced by Návar (2010b) explain physically this variance.

The type of equation may also influence its applicability outside the range for which it was developed. Non-linear models of the type $\mathrm{B}=\mathrm{a}$. $\mathrm{DBH}^{\mathrm{b}}$ are more robust outside the range for which these are developed (e.g., see Fig. 1) and as these approach the fractal allometry of B in relation to DBH (West et al. 1999; Zianis and Mencuccini 2004) in contrast to polynomial models that often present abnormal behavior outside its range, such as negative values or reducing the estimation with increasing DBH.

\section{Conclusions}

Mexico possesses a great wealth of allometric equations to estimate biomass of a high variety of tree species or forest ecosystems. This paper tries to compile the most accessible models published in the literature and to make these available for scientific research, developing national biomass estimations of the forest ecosystem, or to design a scheme to validate the use of each of them. Efforts to improve the database directed toward validating the models under different conditions with cost-effective sampling and modeling procedures, such as those proposed by Zianis and Mencuccini (2004), are key to reduce the uncertainties of the estimations of biomass.

Acknowledgments We would like to thank the anonymous revisers of the earlier drafts of the paper, which resulted in important improvements of the current version. The research was partially funded by ECOSUR, The National Forestry Commission (CONAFOR), the Mexican representation of the United Nations Environmental Programme (PNUD-Mexico), and Programa Mexicano del Carbono. The primary data will be made available through the Globallometree database (http://www. globallometree.org). 


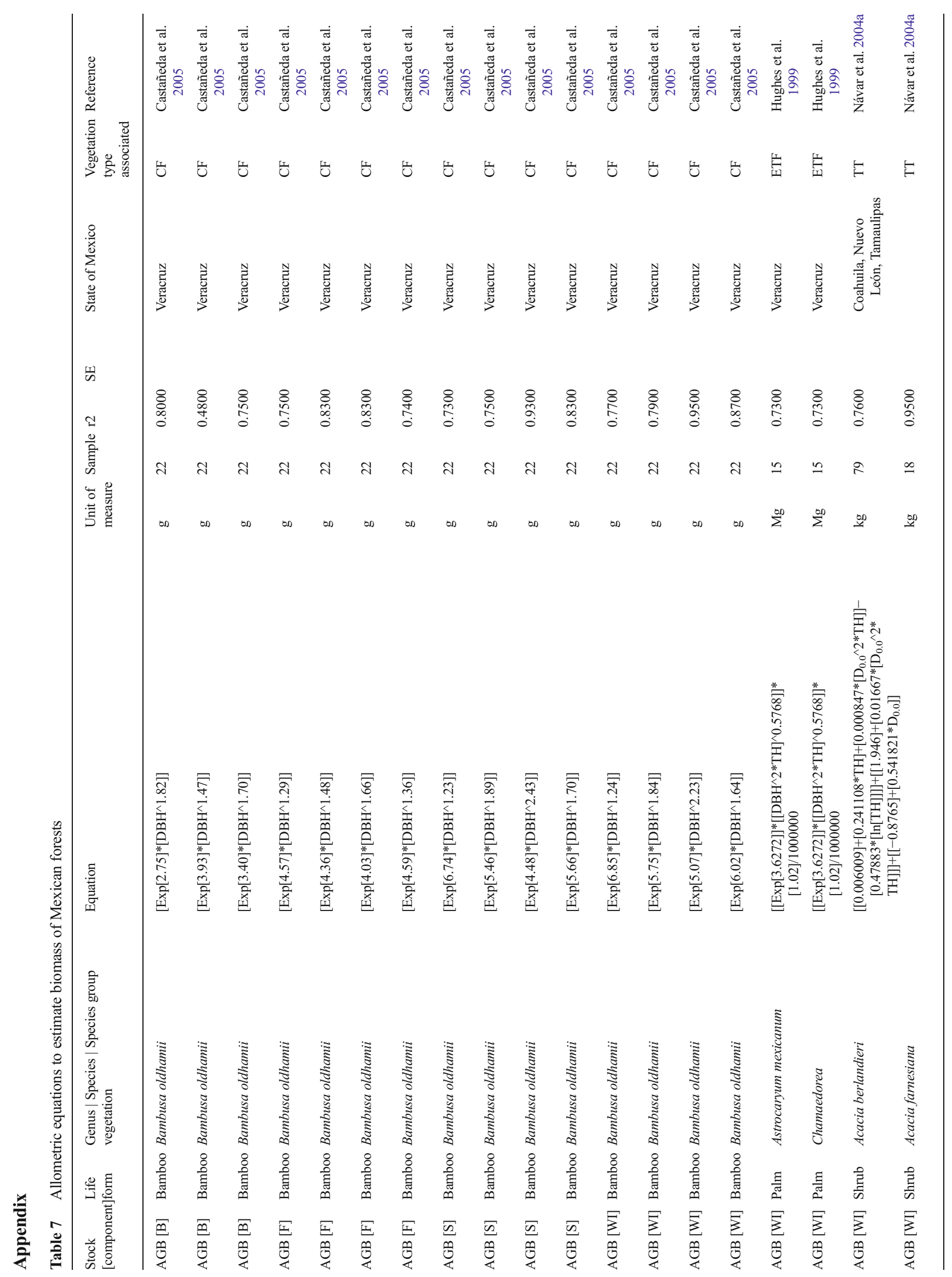




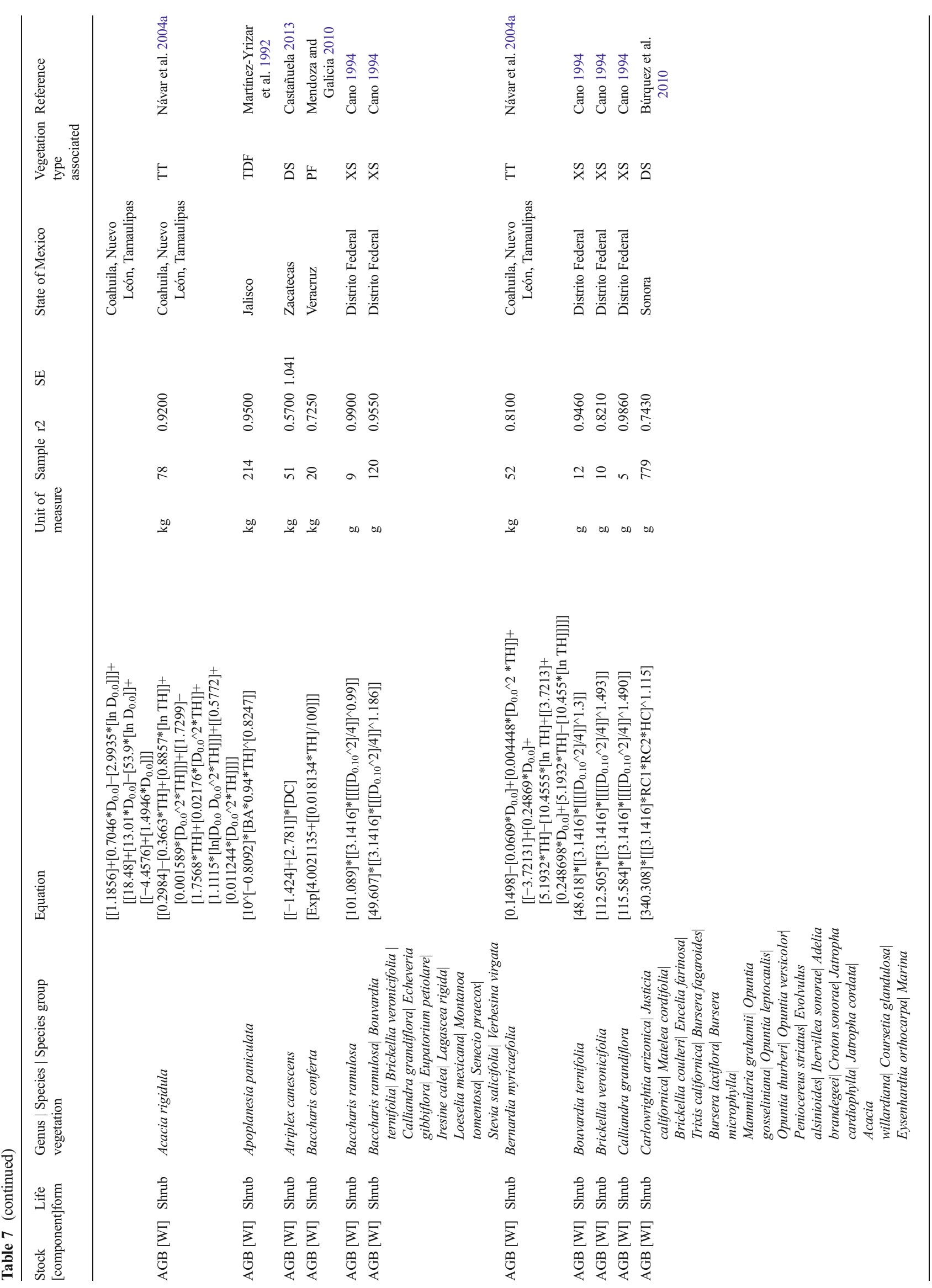




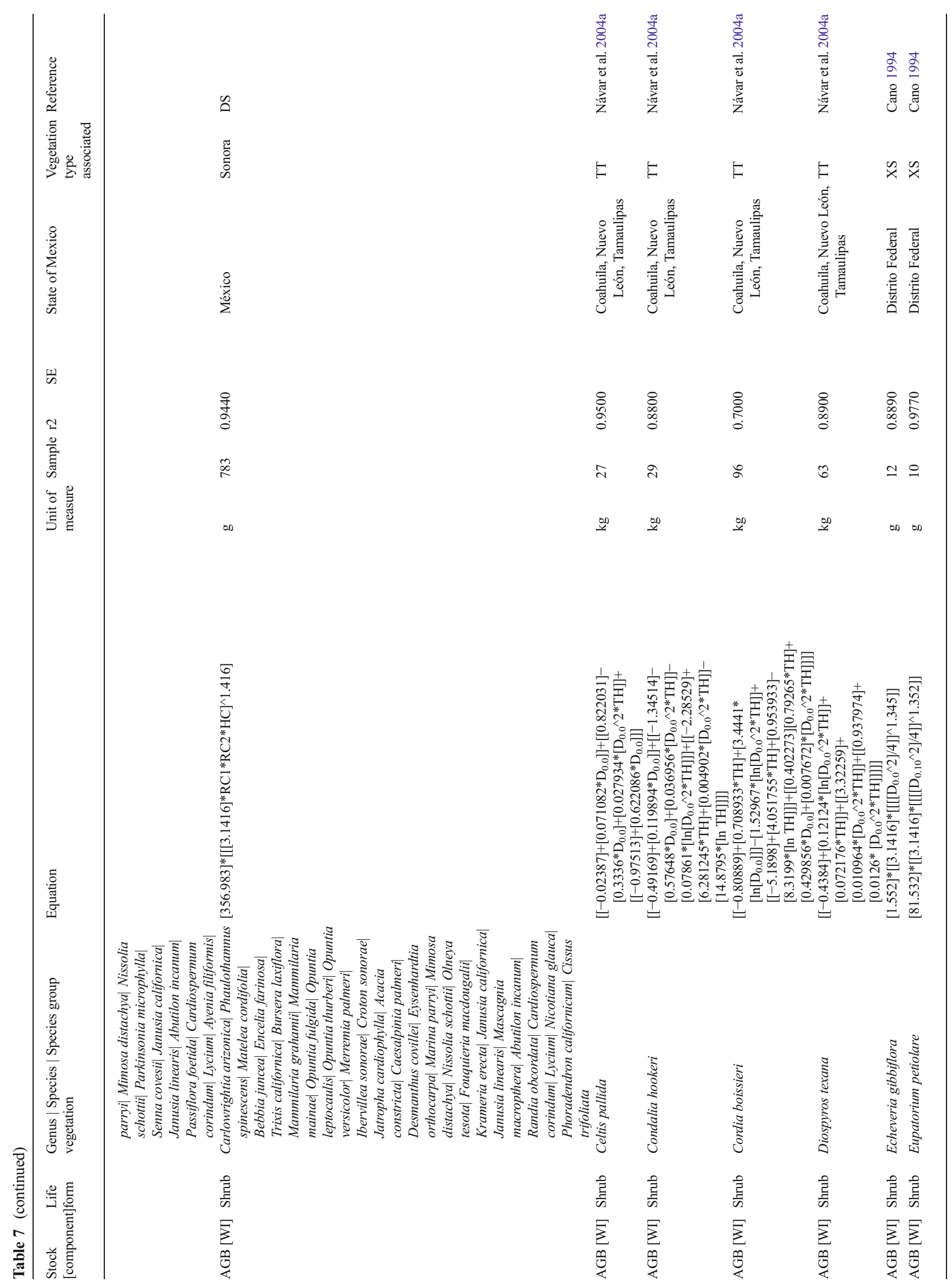




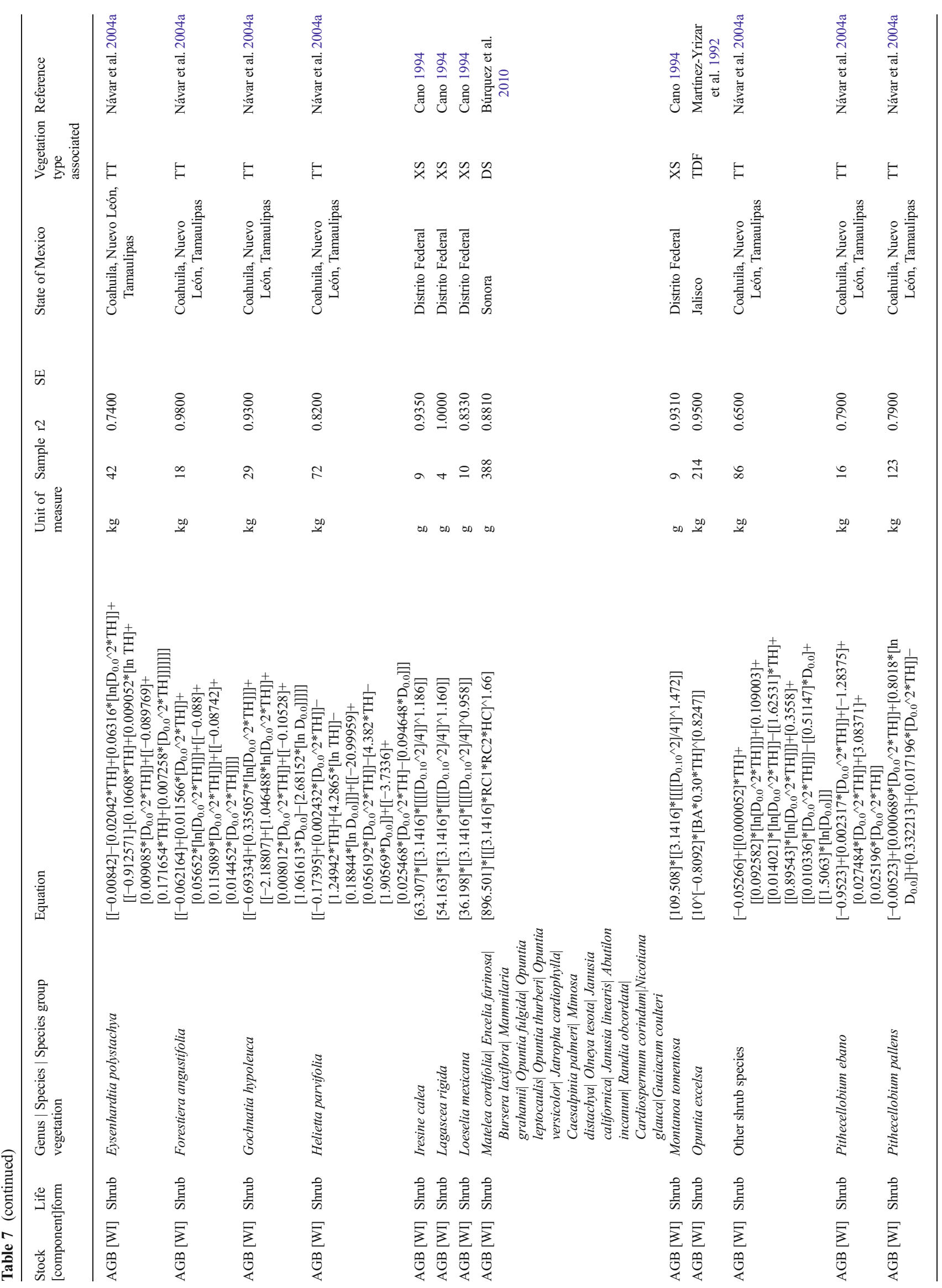




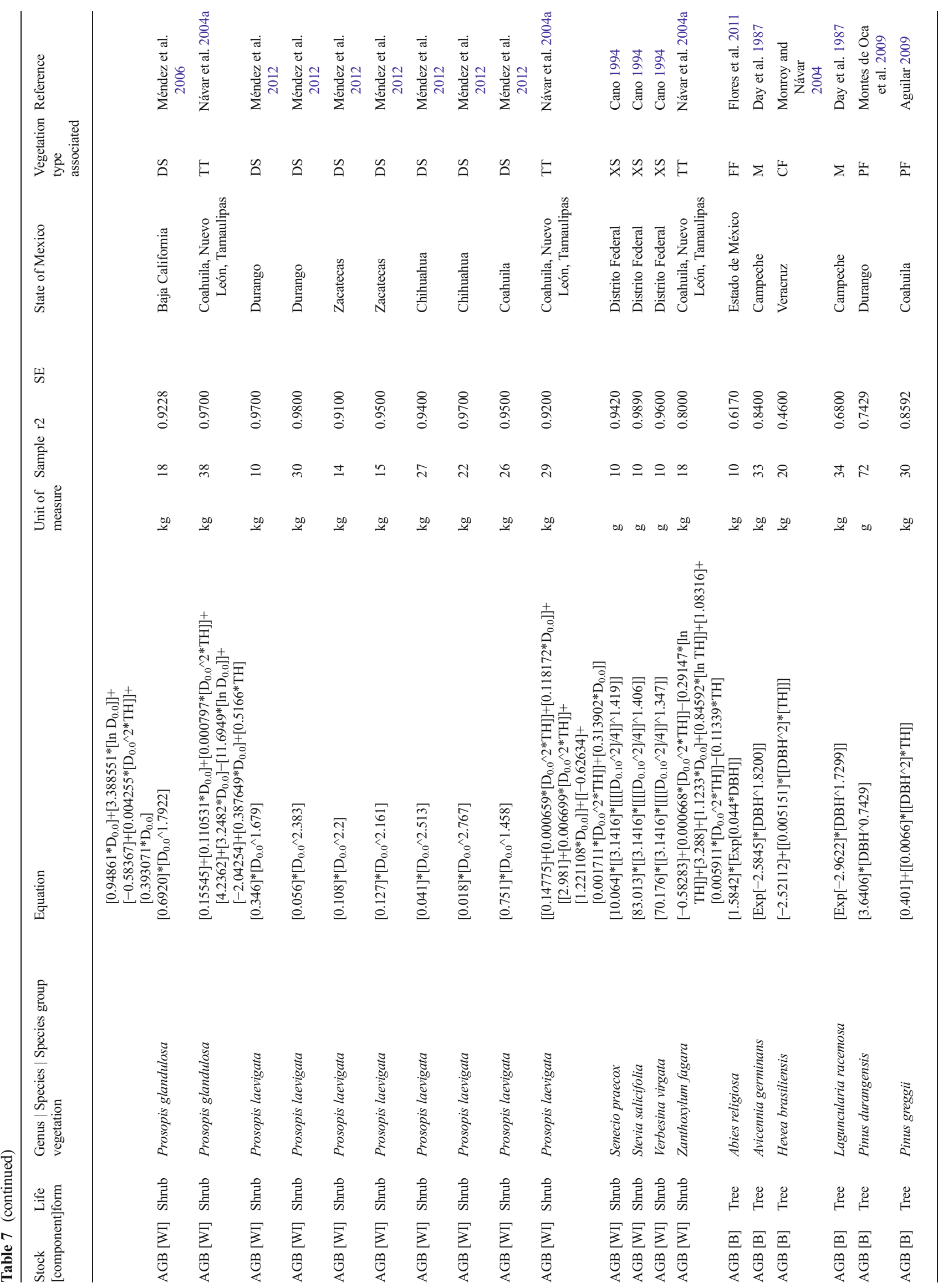




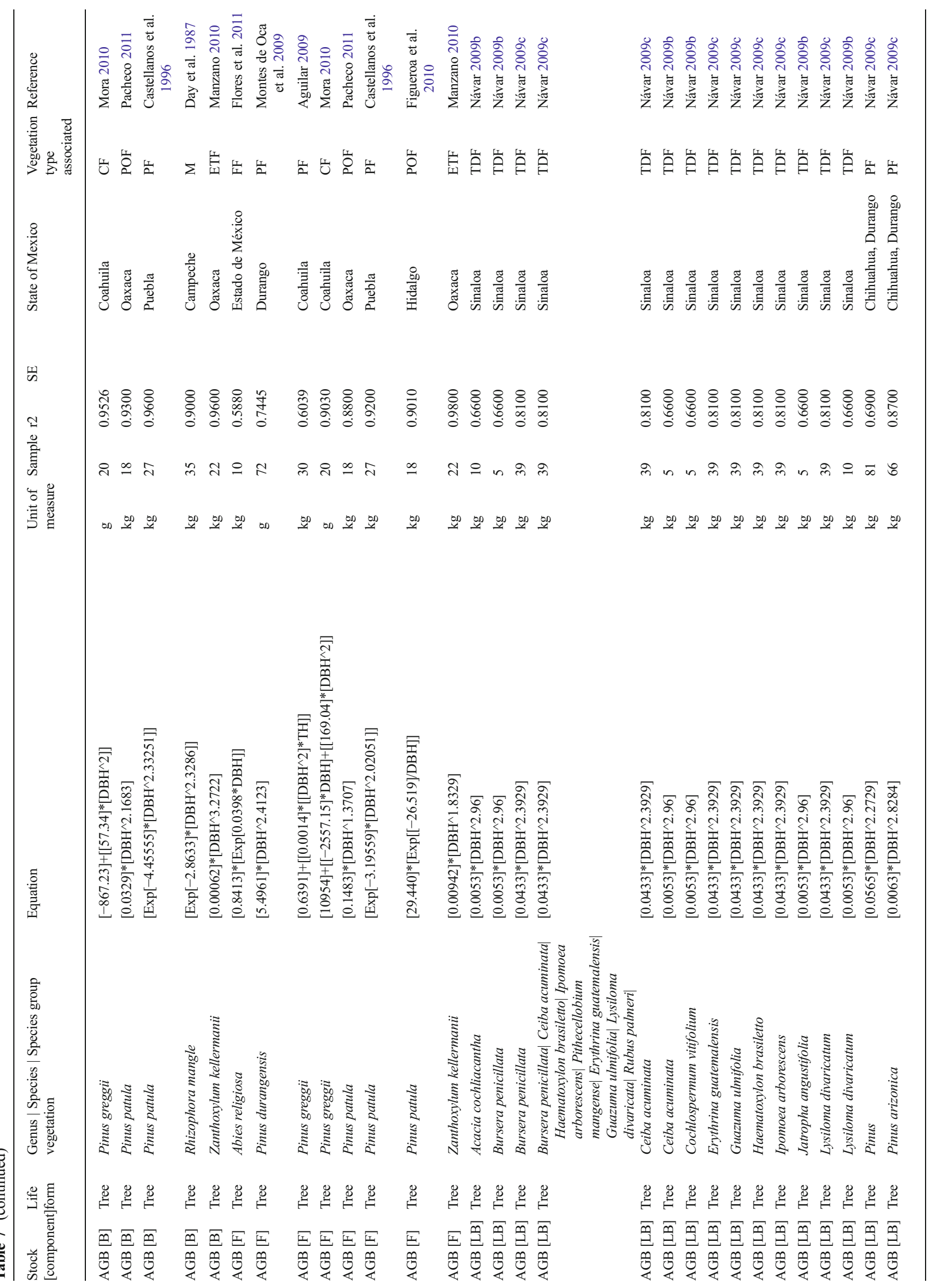




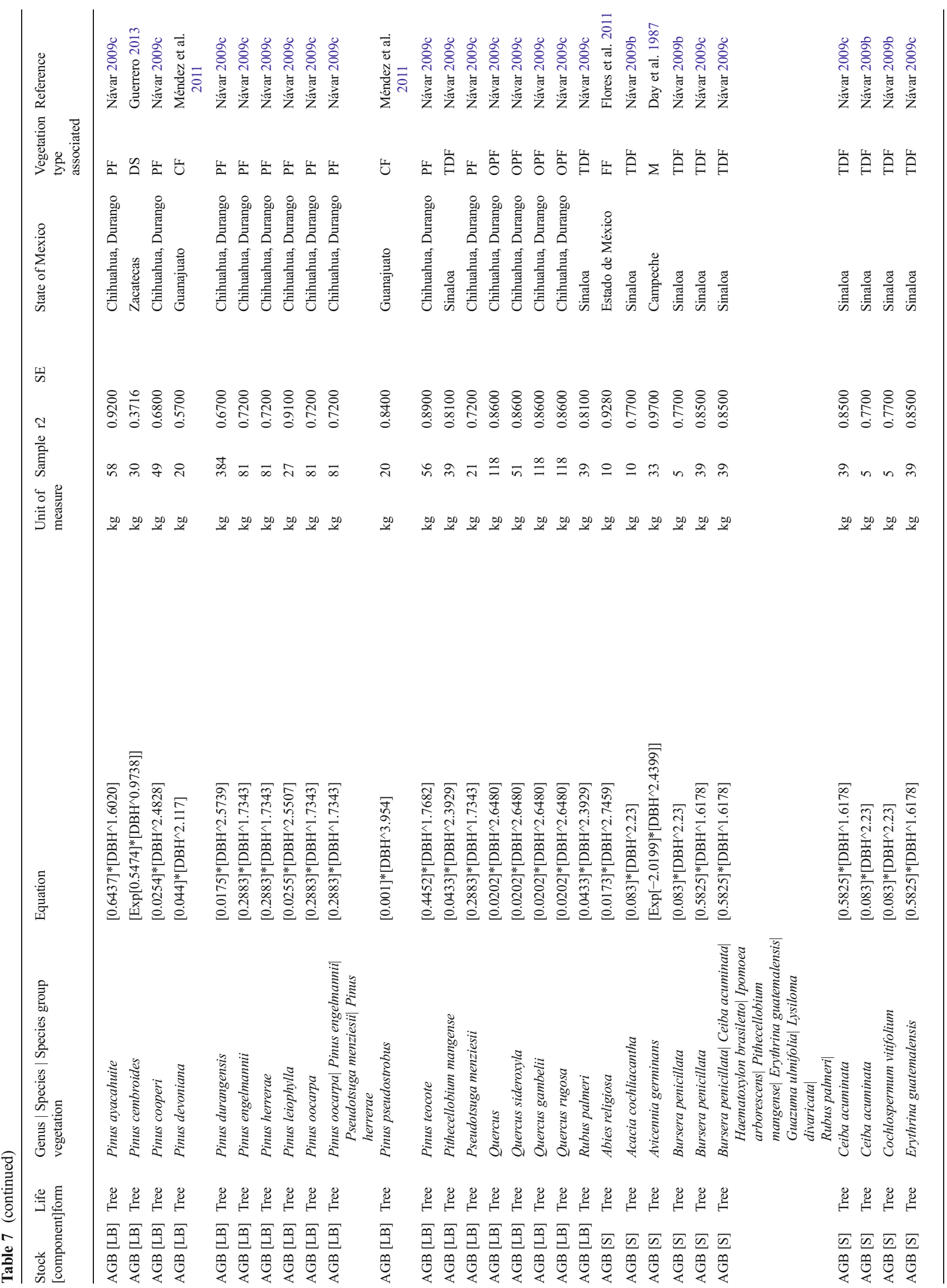




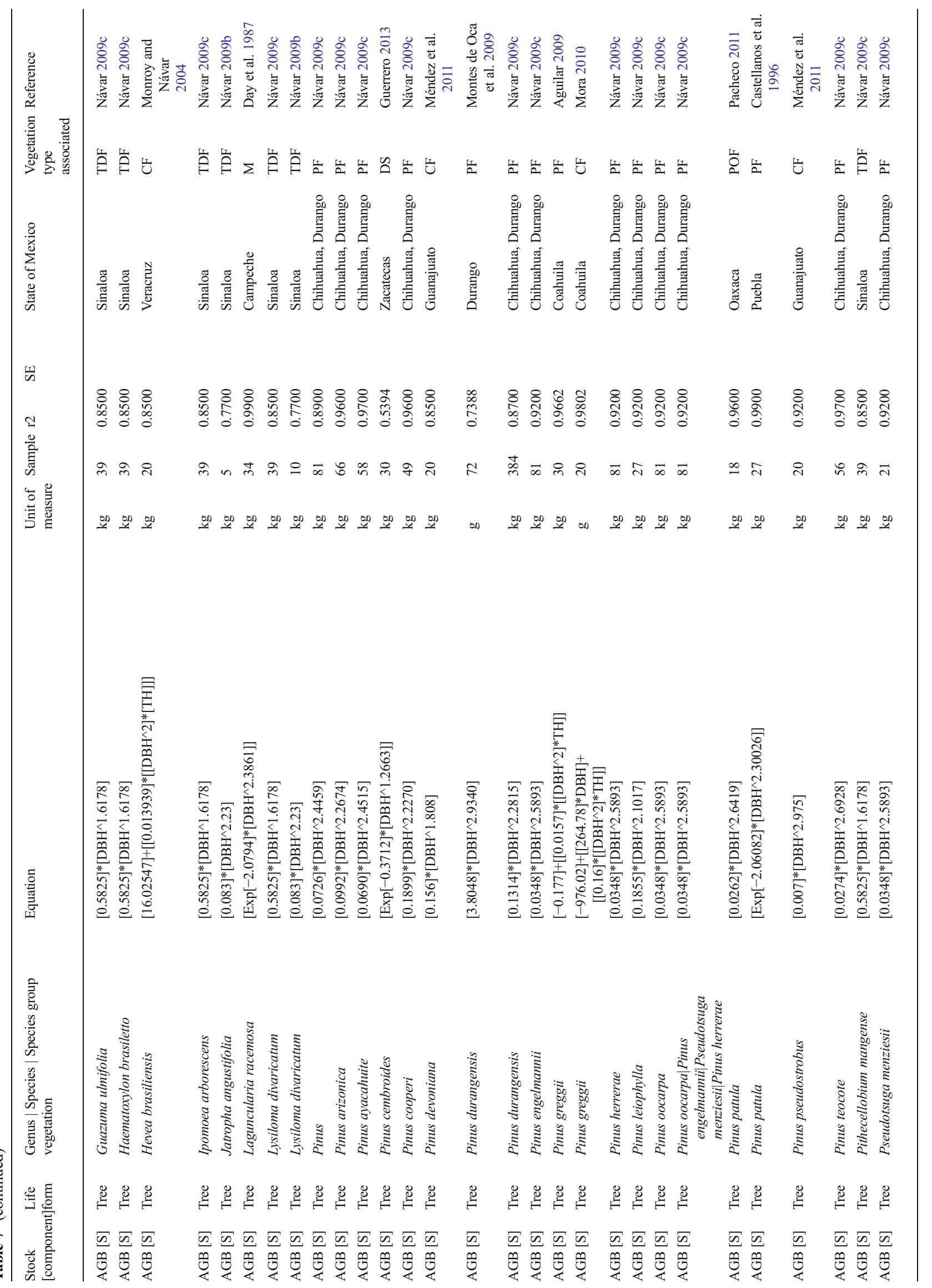




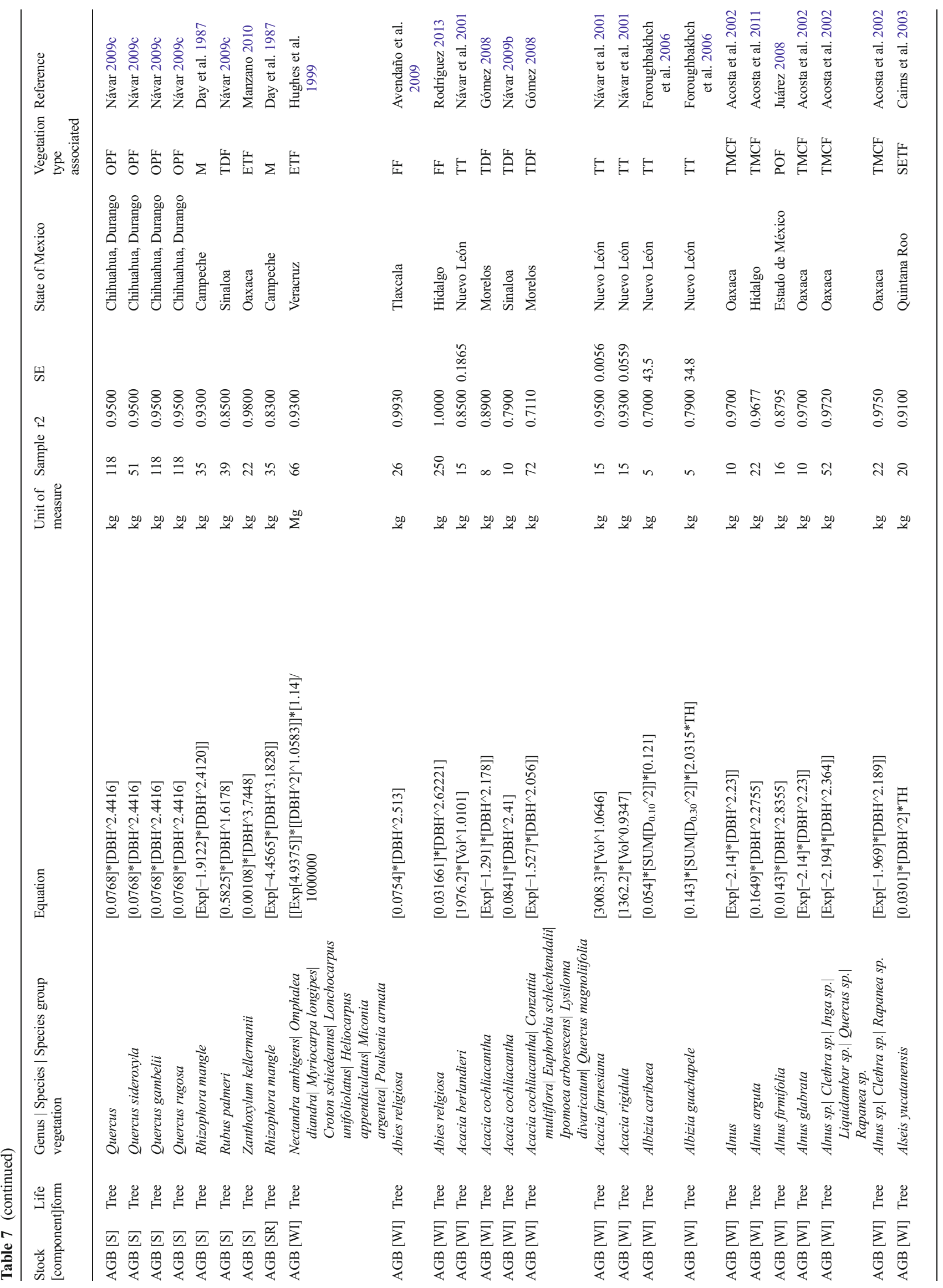




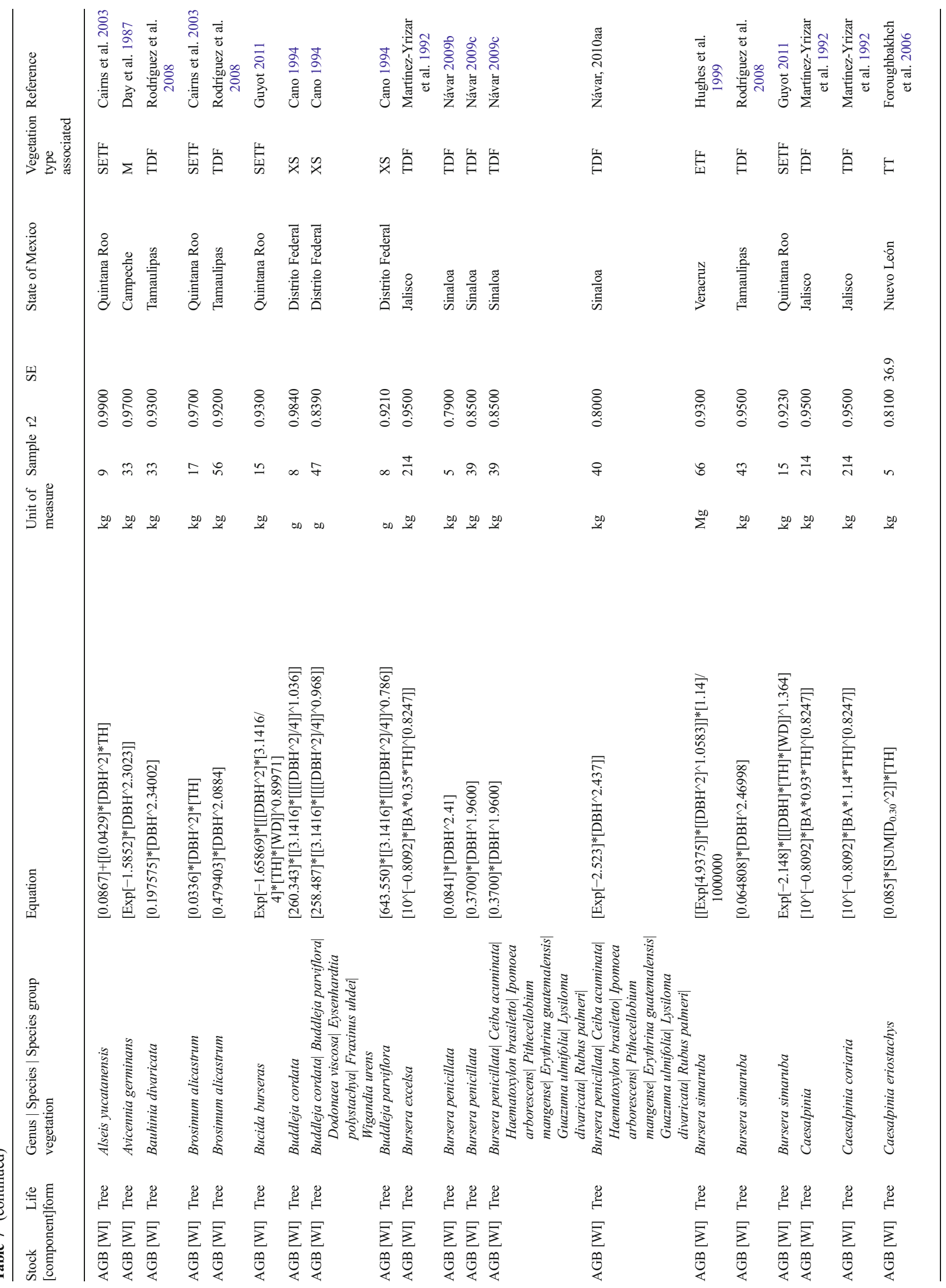




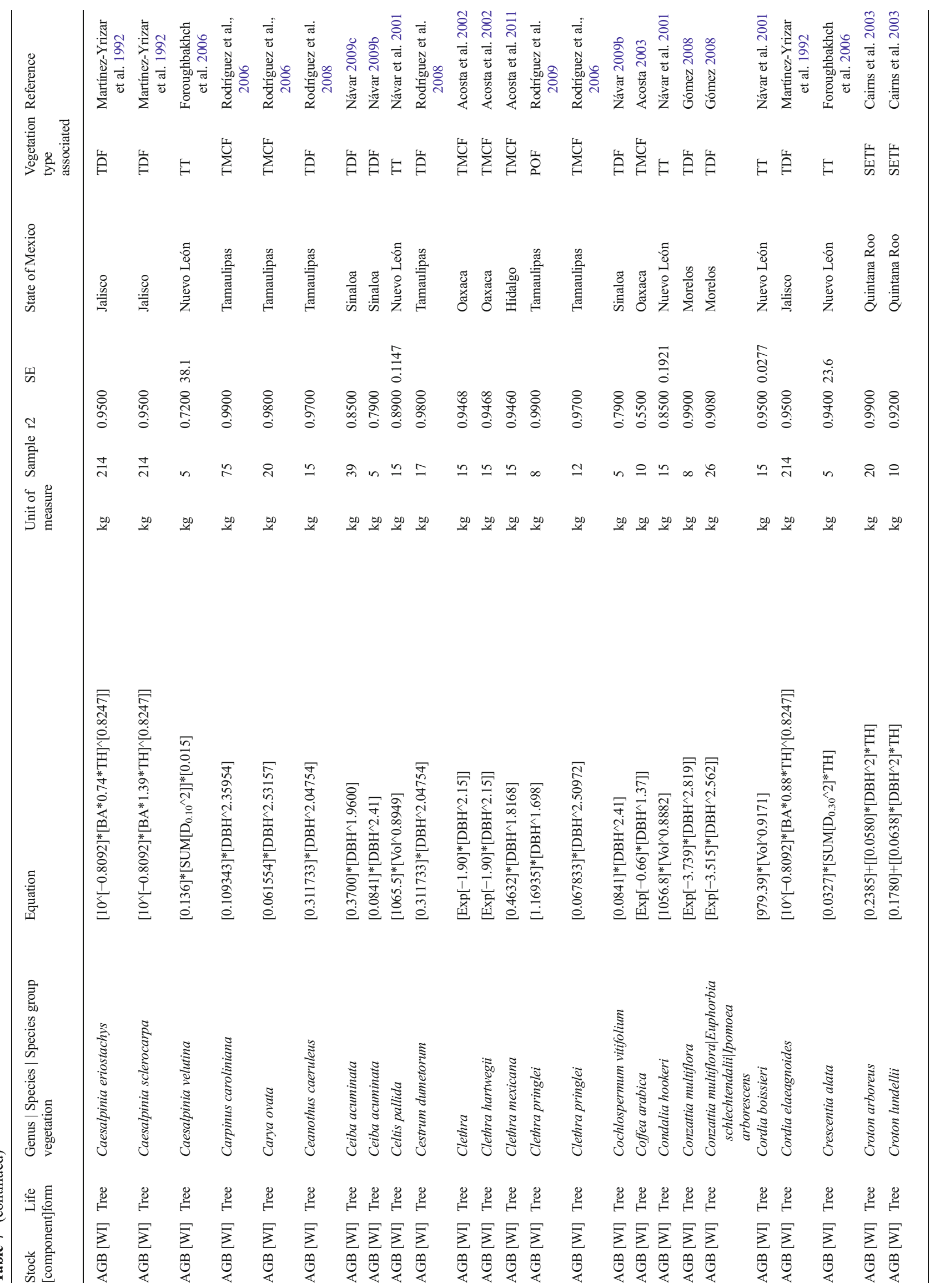




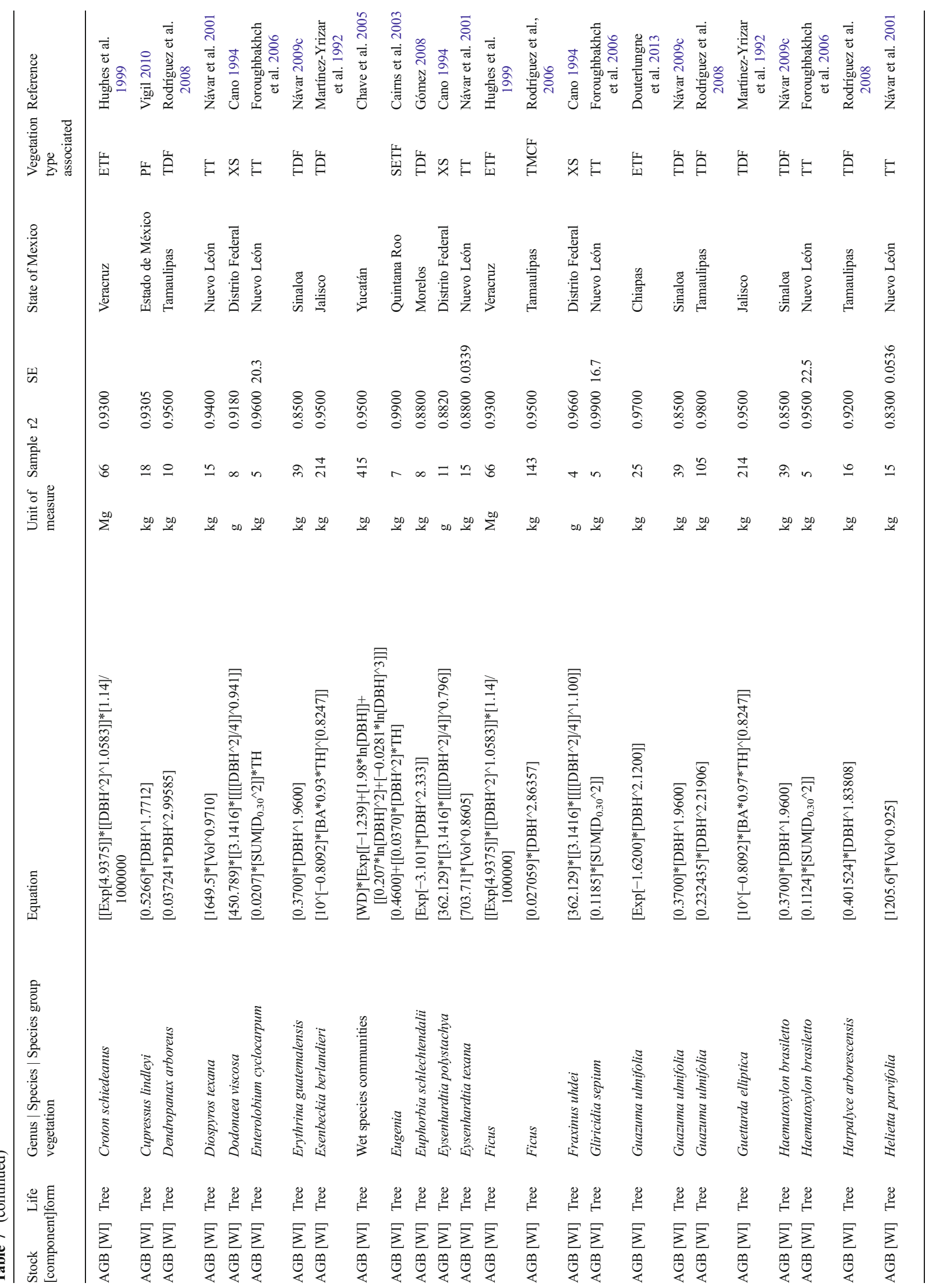




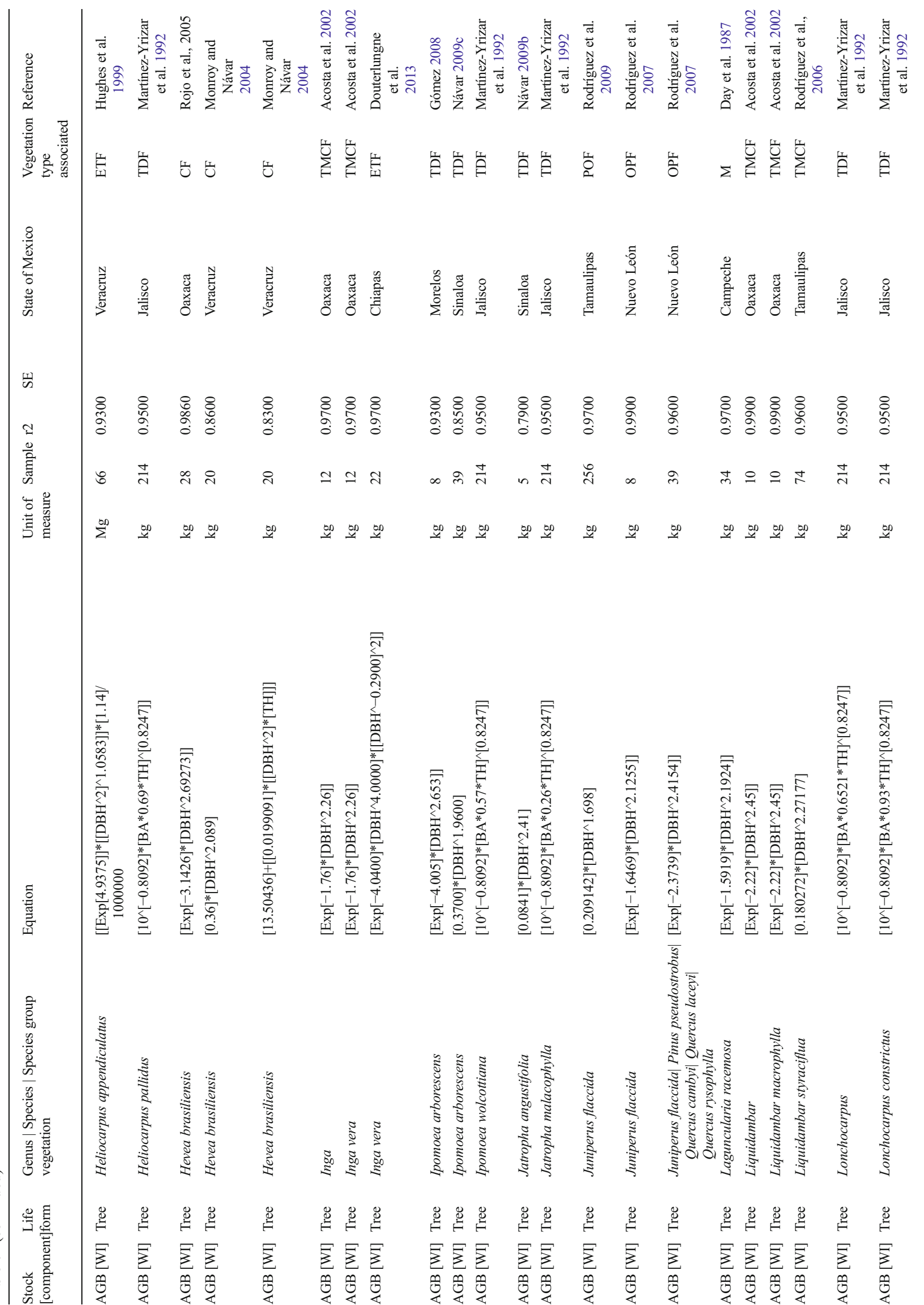




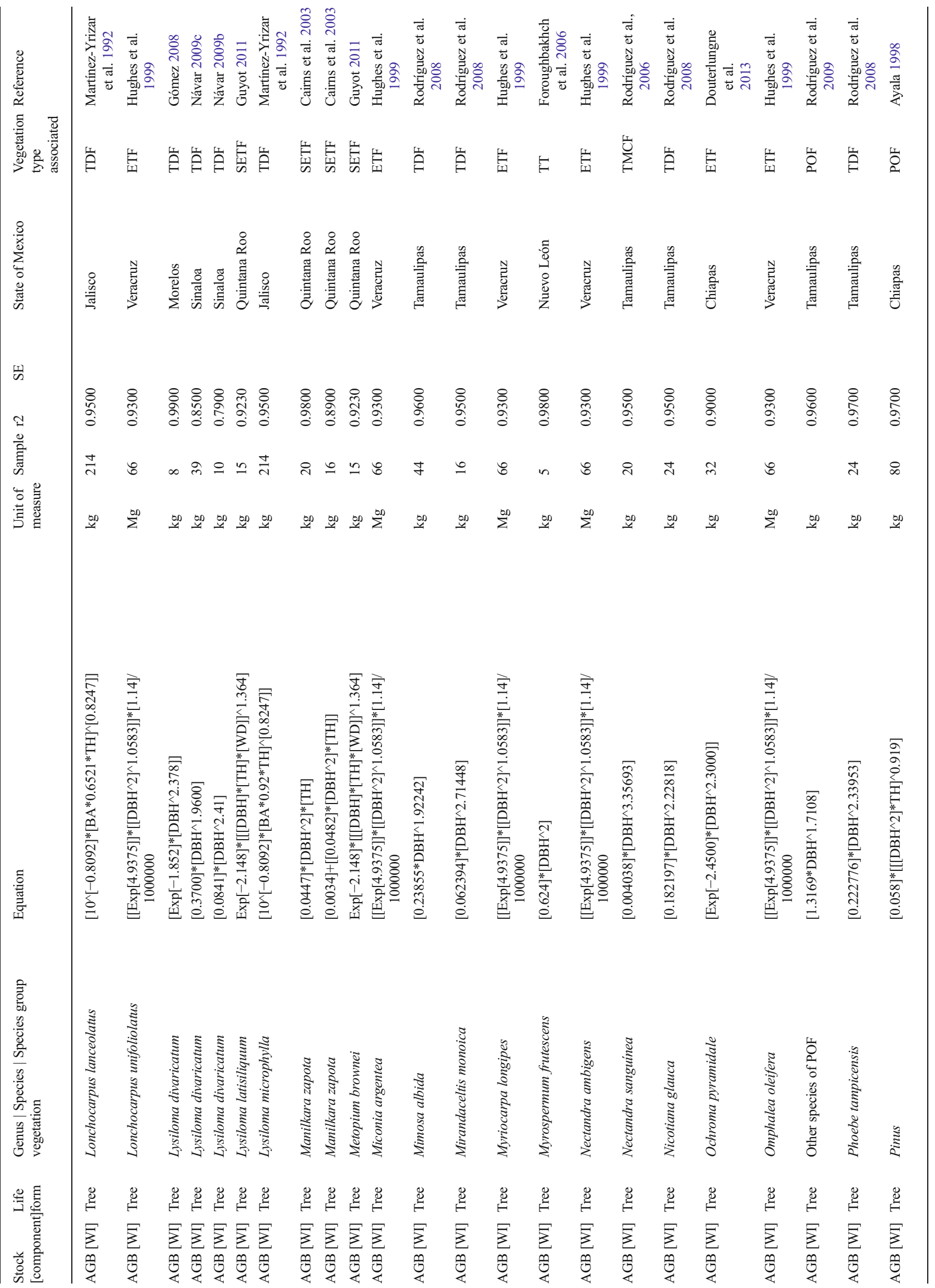




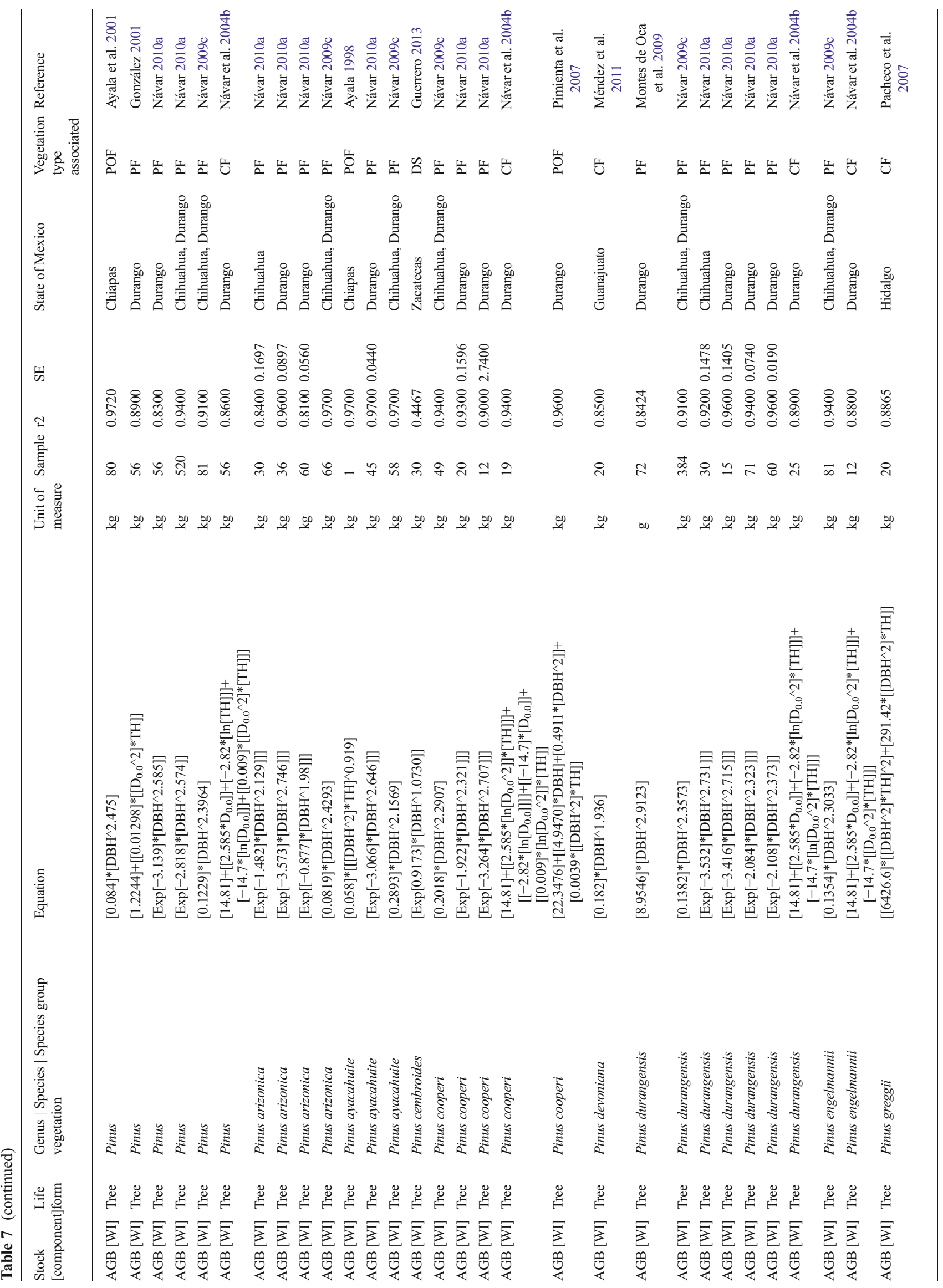




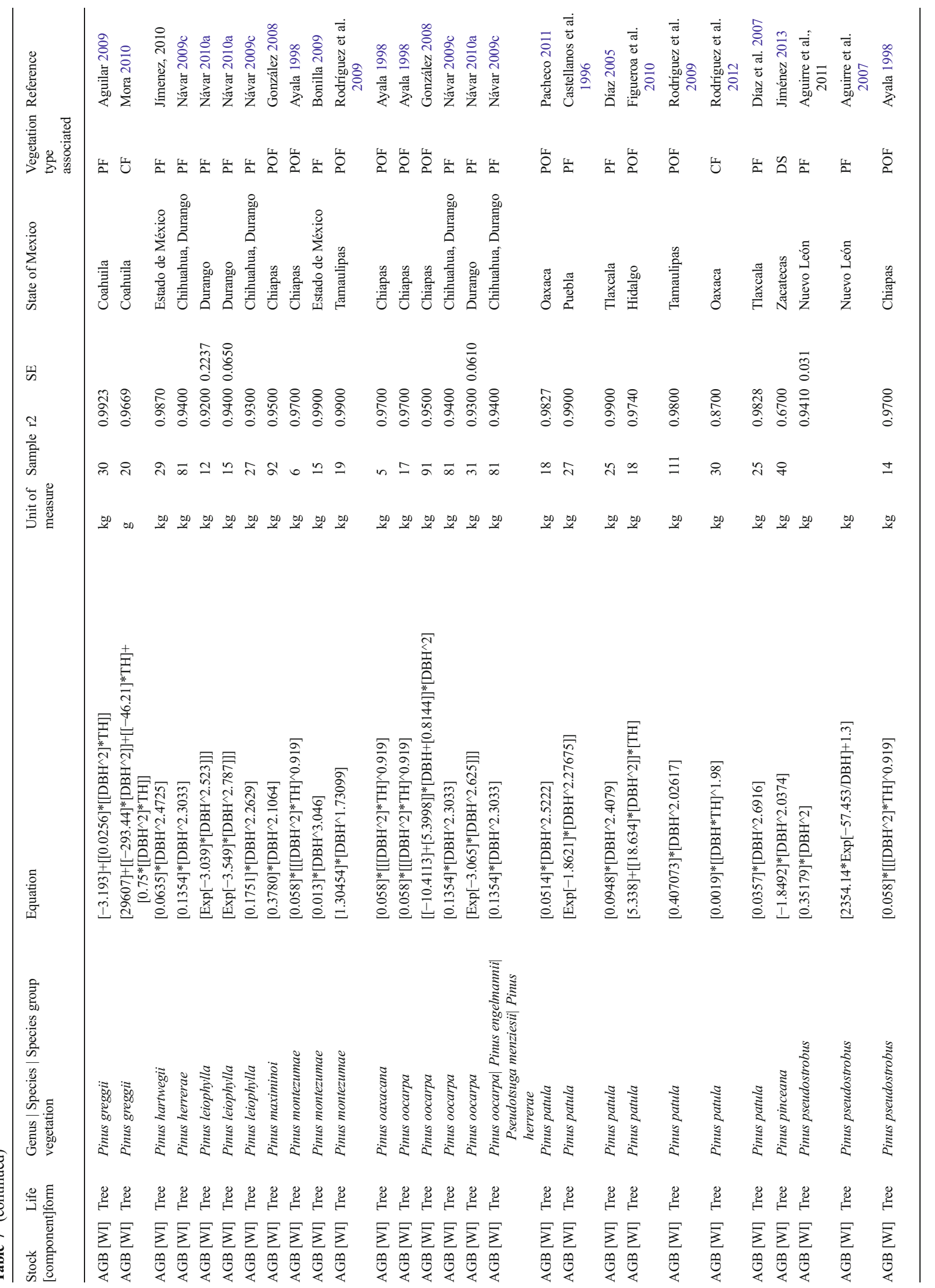




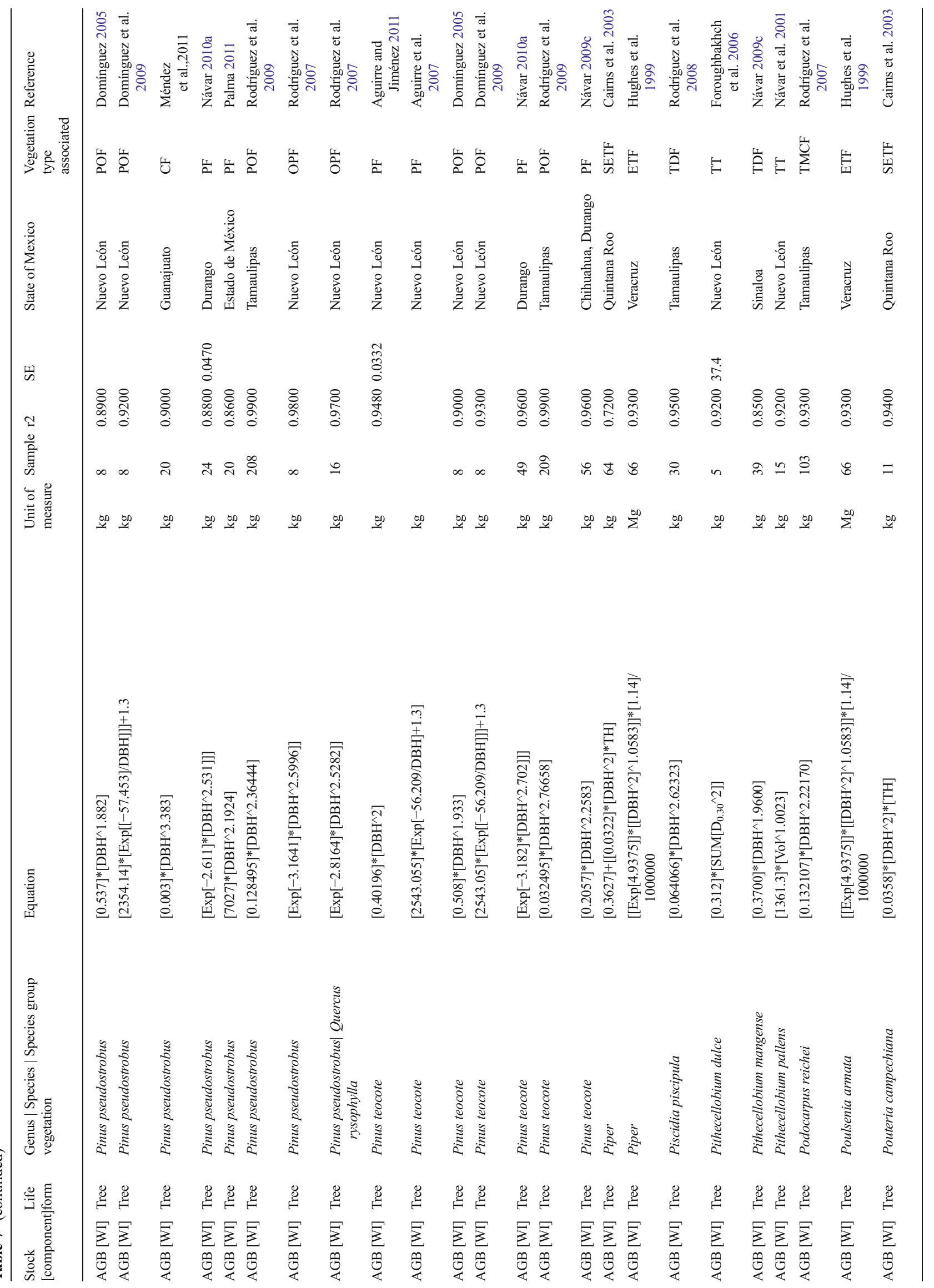




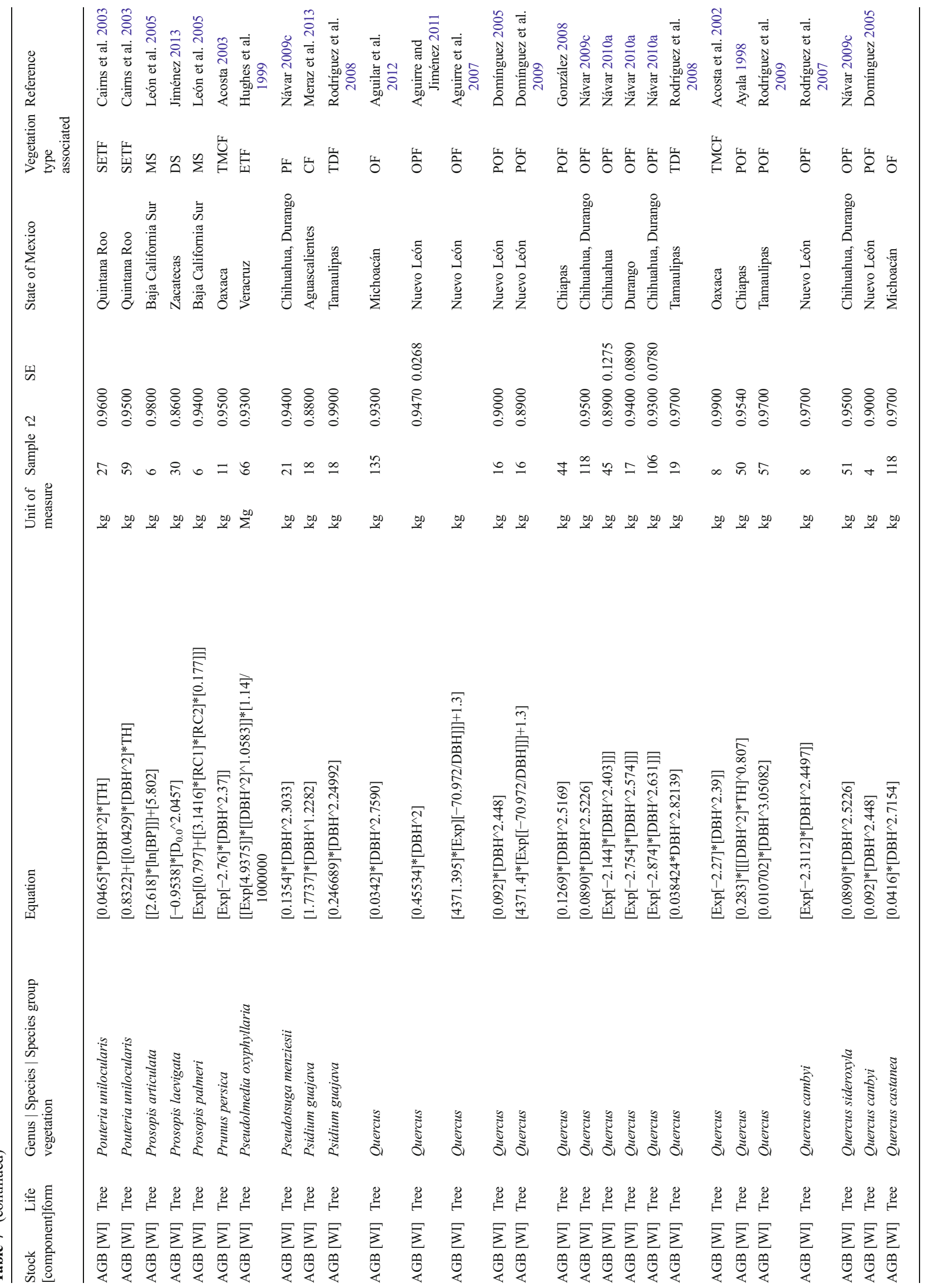




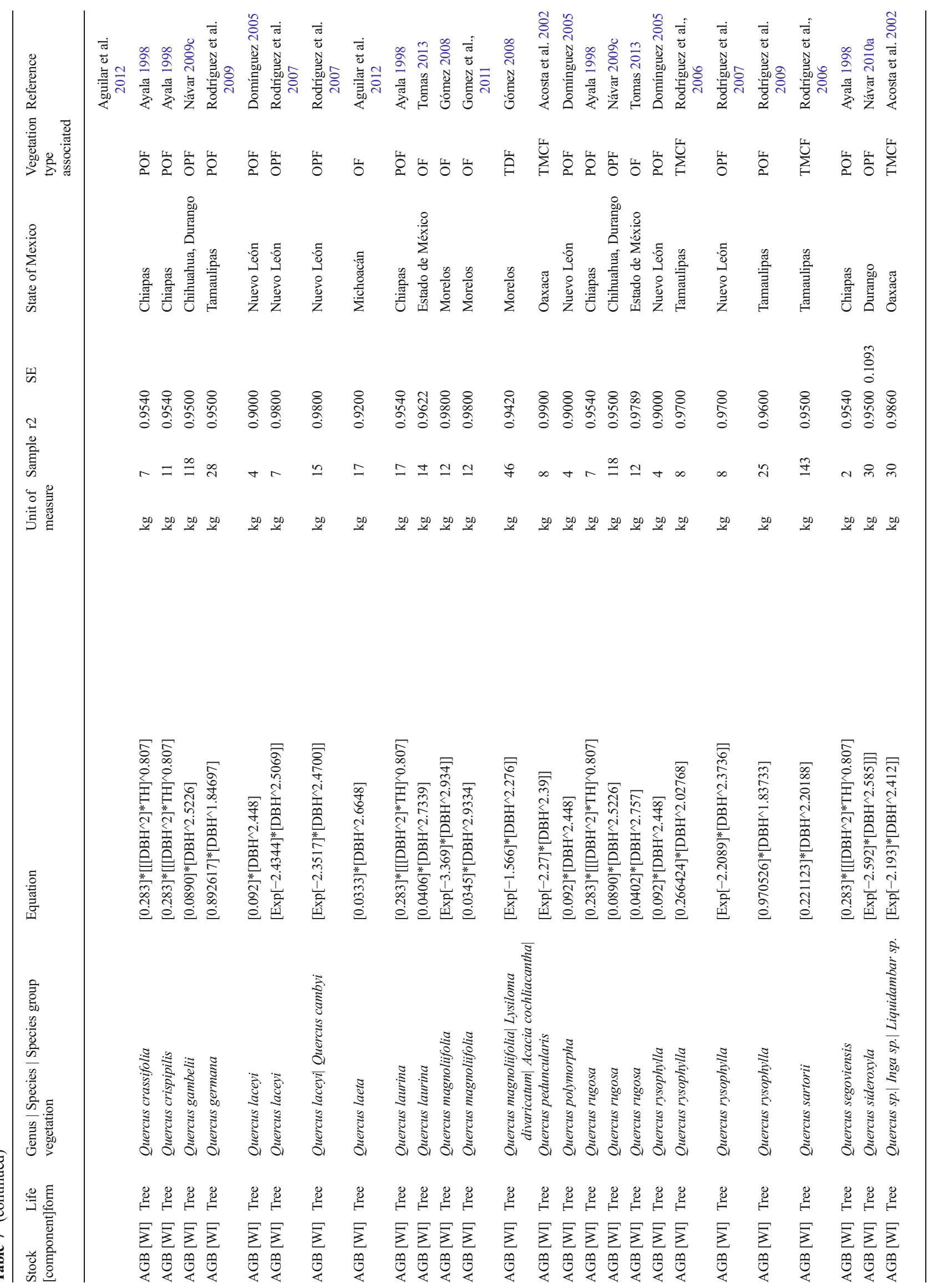




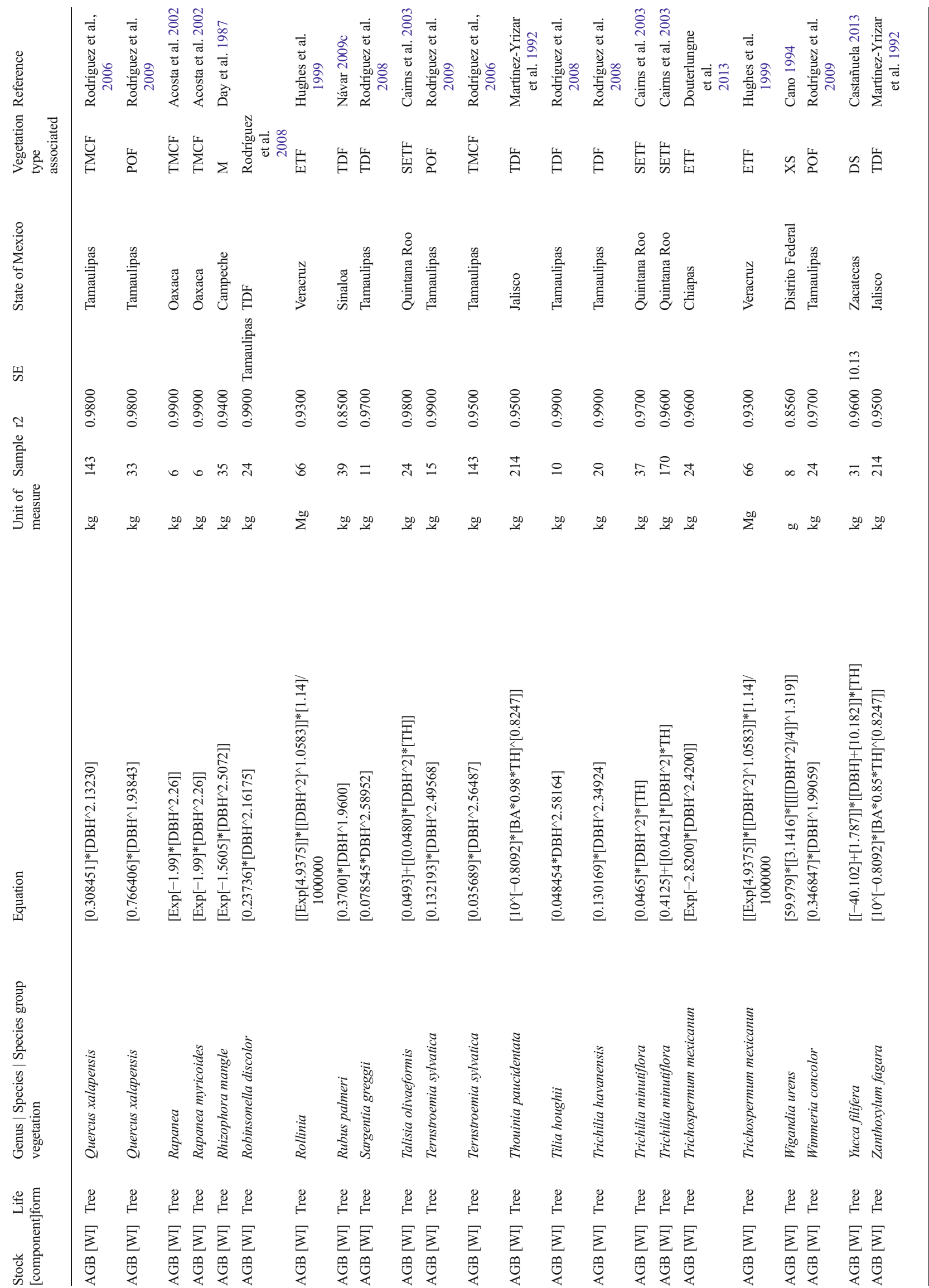




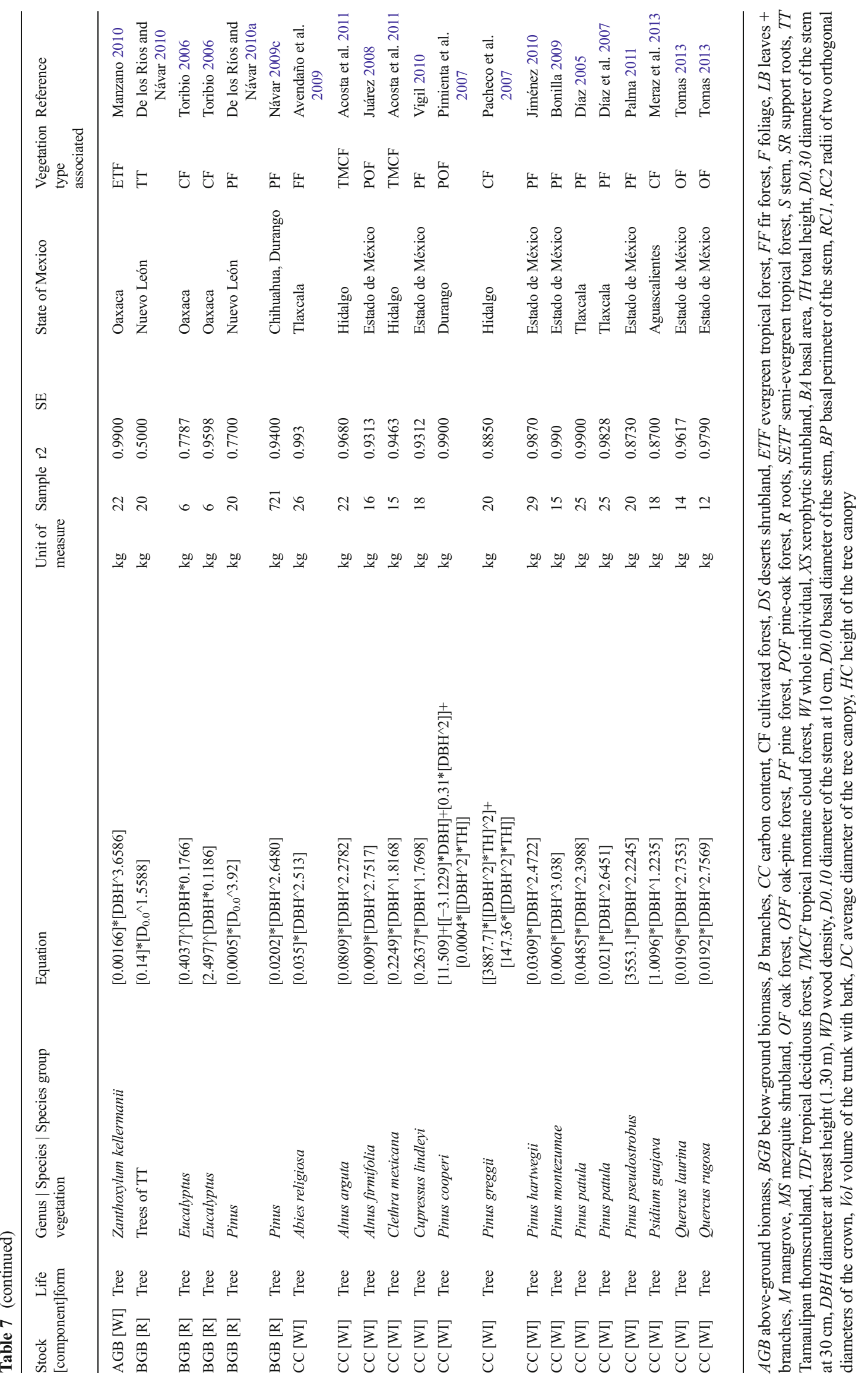




\section{References}

Acosta M (2003) Diseño y aplicación de un método para medir los almacenes de carbono en sistemas con vegetación forestal y agrícolas de ladera de México. Thesis, Colegio de Postgraduados

Acosta M, Vargas J, Velásquez A, Etchevers J (2002) Estimación de la biomasa aérea mediante el uso de relaciones alométricas en seis especies arbóreas en Oaxaca, México. Agrosciencia 36:725-736

Acosta M, Carrillo F, Gómez R (2011) Estimación de biomasa y carbono en dos especies de bosque mesófilo de montaña. Rev Mex de Cienc Agric 2:529-543

Agee JK (1983) Fuel weights of understory-grown conifers in southern Oregon. Can J For Res 13:648-656

Aguilar J (2009) Captura de carbono en una plantación de Pinus greggii Engelm., en Arteaga Coahuila. Thesis, Universidad Autónoma Agraria Antonio Narro

Aguilar R, Ghilardi A, Vega E, Skutsch M, Oyama K (2012) Sprouting productivity and allometric relationships of two oak species managed for traditional charcoal making in central Mexico. Biomass Bioenergy 36:192-207

Aguirre O, Jiménez J (2011) Evaluación del contenido de carbono en bosques del sur de Nuevo León. Rev Mex Cien For 2:73-83

Aguirre O, Jiménez J, Domínguez G, Treviño E (2007) Evaluación del contenido de carbono en bosques del sur de Nuevo León. VIII Congreso Mexicano de Recursos Forestales. Morelia, México 2831 de Octubre de 2007

Avendaño D, Acosta M, Carrillo F, Etchevers J (2009) Estimación de la biomasa y carbono en un bosque de Abies religiosa. Rev Fitotec Mex 32:233-238

Ayala R (1998) Ecuaciones para estimar biomasa de pinos y encinos en la meseta central de Chiapas. Thesis, Universidad Autónoma de Chapingo

Ayala R, De Jong B, Ramírez H (2001) Ecuaciones para estimar biomasa de pinos y encinos en la meseta central de Chiapas. Rev Chapingo Ser Cienc For Am 7:153-157

Baskerville GL (1965) Dry-matter production in immature balsam fir stands. Forest Science Monograph, Society of American Foresters, Washington, DC

Basuki TM, Van Laake PE, Skidmore AK, Hussin YA (2009) Allometric equations for estimating the above-ground biomass in tropical lowland Dipterocarp forests. For Ecol Manage 257:1684-1694

Bombelli A, Avitabile V, BelelliMarchesini L, Balzter H, Bernoux M, Hall R, Henry M, Law BE, Manlay R, Marklund LG, Shimabukuro YE (2009) Assessment of the status of the development of the standards for the terrestrial essential climate variables: biomass. Food and Agriculture Organization- Global Terrestrial Observation System, Rome

Bonilla E (2009) Uso de ecuaciones alométricas para estimar biomasa y carbono en Pinus montezumae Lamb. Thesis, Universidad Autónoma Chapingo

Bravo F, Delgado JA, Gallardo JF, Bravo-Oviedo A, Ruiz-Peinado R, Merino A, Montero G, Cámara A, Navarro R, Ordóñez C, Canga E (2007) Métodos para cuantificar la fijación de $\mathrm{CO}_{2}$ en los sistemas forestales. In: Bravo Oviedo F (coord.) El papel de los bosques españoles en la mitigación del cambio climático. Fundación Gas Natural. España

Brown S (1997) Estimating biomass and biomass change of tropical forests: a primer. FAO forestry paper no 134 . ISBN 92-5-103955-0

Brown S (2001) Measuring carbon in forests: current status and future challenges. Environ Pollut 116:363-372

Búrquez A, Martínez A, Núñez S, Quintero T, Aparicio A (2010) Aboveground biomass in three sonoran desert communities: variability within and among sites using replicated plot harvesting. J Arid Environ 74:1240-1247
Cairns M, Olmsted I, Granados J, Argaez J (2003) Composition and aboveground tree biomass of a dry semi-evergreen forest on Mexico's Yucatan Peninsula. For Ecol Manage 186:125-132

Cano Z (1994) Flujo de energía a través de Sphenarium purpurascens (Orthopteta: Acrididae) y productividad primaria neta aérea en una comunidad xerófita. Thesis, Universidad Nacional Autónoma de México

Castañeda A, Vargas J, Gómez A, Valdez J, Vaquera H (2005) Acumulación de carbono en la biomasa aérea de una plantación de Bambusa oldhamii. Agrosciencia 39:107-116

Castañuela Y (2013) Estimación de la biomasa aérea y captura de carbono en Yucca filifera (Chaubad) y Atriplex canascens (Pursh) Nutt. usando ecuaciones alométricas, en Mazapil, Zacatecas. Thesis, Universidad Autónoma Agraria Antonio Narro

Castellanos J, Velázquez A, Vargas J, Rodríguez C, Fierros A (1996) Producción de biomasa en un rodal de Pinus patula. Agrosciencia 30:123-128

Cayuela L, Granzow I, Albuquerque F, Golicher DS (2012) Taxonstand: an $\mathrm{R}$ package for species names standardization in vegetation databases. Methods Ecol Evol 3:1078-1083

Chave J, Réjou-Méchain M, Búrquez A, Chidumayo E, Colgan M, Delitti W, Duque A, Eid T, Fearnside P, Goodman R, Henry M, MartínezYrízar A, Mugasha W, Muller-Landau H, Mencuccini M, Nelson B, Ngomanda A, Nogueira E, Ortiz-Malavassi E, Pélissier R, Ploton P, Ryan C, Saldarriaga J, Vieilledent G (2014) Improved allometric models to estimate the aboveground biomass of tropical trees. Glob Chang Biol Bioenergy 20:3177-3190

Chave J, Andalo C, Brown S, Cairns M, Chambers J, Eamus D, Fölster H, Fromard F, Higuchi N, Kira T, Lescure J, Nelson B, Ogawa H, Puig H, Riéra B, Yamakura T (2005) Tree allometry and improved estimation of carbon stocks and balance in tropical forests. Oecologia 145:87-99

Clark DA, Brown S, Kicklighter DW, Chambers JQ, Thomlinson JR, Ni J, Holland EA (2001) Net primary production in tropical forests: an evaluation and synthesis of existing field data. Ecol Appl 11:371384

Day J, Conner W, Ley-Lou F, Day R, Machado A (1987) The productivity and composition of mangrove forests, Laguna de Términos, México. Aquat Bot 27:267-284

De Jong B, Rojas-García F, Olguín-Álvarez M, Martínez-Zurimendi P (2009) Base de datos con ecuaciones alométricas de árboles y arbustos de bosques y selvas de México. El Colegio de la Frontera Sur Unidad, Villahermosa

De los Rios E, Návar J (2010) Alometría de raíces de dos comunidades subtropicales del Nordeste de México. Trop Subtrop Agroecosyt 12: $123-134$

R Development Core Team (2012) R: a language and environment for statistical computing. R foundation for statistical computing, Vienna, Austria.ISBN 3-900051-07-0. http://www.R-project.org/

Díaz R (2005) Determinación de ecuaciones alométricas para estimar biomasa y carbono en el estrato aéreo en bosques de Pinus patula Schl. Cham. en Tlaxcala México. Thesis, Universidad Nacional Autónoma Chapingo

Díaz R, Acosta M, Carrillo F, Buendía E, Flores E, Etchevers J (2007) Determinación de ecuaciones alométricas para estimar biomasa y carbono en Pinus patula Schl. Cham Madera Bosques 13:25-34

Dietze MC, Wolosin MS, Clark JS (2008) Capturing diversity and interspecific variability in allometries: a hierarchical approach. For Ecol Manag 256:1939-1948

Domínguez G (2005) Evaluación del contenido de carbono en bosques del sur de Nuevo León. Thesis, Universidad Autónoma de Nuevo León

Domínguez G, Aguirre O, Jiménez J, Rodríguez R, Díaz J (2009) Biomasa aérea y factores de expansión de especies arbóreas en bosques del sur de Nuevo León. Rev Chapingo Ser Cienc For Am 15:59-64 
Douterlungne D, Herrera A, Ferguson B, Siddique I, Soto L (2013) Ecuaciones alométricas para estimar biomasa y carbono de cuatro especies leñosas neotropicales con potencial para la restauración. Agrosciencia 47:385-397

FAO, Food and Agriculture Organization of the United Nations (2013) Globallometree: the international tree allometric equation platform. http://www.fao.org/forestry/fma/80797/en/

Fehrmann L, Kleinn C (2006) General considerations about the use of allometric equations for biomass estimation on the example of Norway spruce in central Europe. For Ecol Manag 236:412-421

Figueroa C, Ángeles G, Velázquez A, de los Santos H (2010) Estimación de la biomasa en un Bosque bajo manejo de Pinus patula Schltdl. et Cham en Zacualtipán, Hidalgo. Rev Mex Cien For 1:105-112

Flores P, López M, Ángeles G, de la Isla M, Calva G (2011) Modelos para estimación y distribución de biomasa de Abies religiosa (Kunth) Schltdl. et Cham. en proceso de declinación. Rev Mex Cien For 2:920

Foroughbakhch R, Alvarado M, Hernández J, Rocha A, Guzmán M, Treviño E (2006) Establishment, growth and biomass production of 10 tree woody species introduced for reforestation and ecological restoration in northeastern Mexico. For Ecol Manag 235:194-201

Gómez J (2008) Determinación de los almacenes de carbono en los compartimentos aéreo y subterráneo de dos tipos de vegetación en la reserva de la biósfera Sierra de Huautla, Morelos, México. Thesis, Colegio de Postgraduados

Gómez J, Etchevers J, Monterrosos A, Campo J, Tinoco J (2011) Ecuaciones alométricas para estimar biomasa y carbono en Quercus magnoliaefolia. Rev Chapingo Ser Cienc For Am 17: 261-272

González N (2001) Ajuste y validación de modelos para estimar biomasa $\mathrm{y}$ crecimiento de biomasa en plantaciones forestales del estado de Durango. Thesis, Universidad Autónoma de Nuevo León

González M (2008) Estimación de la biomasa aérea y la captura de carbono en regeneración natural de Pinus maximinoi H. E. Moore, Pinus oocarpa var. ochoterenai Mtz. Y Quercus sp. en el norte del Estado de Chiapas, México. Thesis, Centro Agronómico Tropical de investigación y Enseñanza

Guerrero L (2013) Cuantificación de biomasa, carbono y producción de oxígeno de Pinus cembroides Zucc. En Mazapil, Zacatecas, México. Thesis, Universidad Autónoma Agraria Antonio Narro

Guyot J (2011) Estimation du stock de carbone dans la végétation des zones humides de la Péninsule du Yucatan. Mémoire de fin détudes. AgroParis Tech- El Colegio de la Frontera Sur, France

Henry M, Bombelli A, Trotta C, Alessandrini A, Birigazzi L, Sola G, Vieilledent G, Santenoise P, Longuetaud F, Valentini R, Picard N, Saint-André L (2013) GlobAllomeTree: international platform for tree allometric equations to support volume, biomass and carbon assessment. For 6:326-330

Hughes F, Kauffman B, Jaramillo V (1999) Biomass, carbon, and nutrient dynamics of secondary forests in a humid tropical region of Mexico. Ecology 80:1892-1907

Jiménez C (2010) Uso de ecuaciones alométricas para estimar biomasa y carbono en la parte aérea de Pinus hartwegii Lindl., en el Parque Nacional Izta-Popo. Thesis, Universidad Autónoma Chapingo

Jiménez E (2013) Ecuaciones alométricas para estimación de biomasa aérea en Prosopis laevigata Willd. y Pinus pinceana Gordon. Thesis, Universidad Autónoma Agraria Antonio Narro

Joosten R, Schumacher J, Wirth C, Schulte A (2004) Evaluating tree carbon predictions for beech (Fagus sylvatica L.) in western Germany. For Ecol Manag 189:87-96

Juárez B (2008) Uso de ecuaciones alométricas para estimar de biomasa y carbono de Alnus jorullensis H.B.K. spp. jurullensis en bosques mezclados de Tequexquinahuac, Texcoco, México. Thesis, Universidad Autónoma Chapingo

León J, Domínguez R, Díaz S (2005) Evaluación del peso del leño a partir de variables dimensionales en dos especies de mezquite Prosopis aticulata S. Watson y P. palmeri S. Watson, en Baja California Sur, México. Act Bot Mex 72:17-32

Manzano F (2010) Crecimiento, periodicidad y biomasa de Zanthoxylum kellermanii P. Wilson en una selva perennifolia del norte de Oaxaca. Thesis, Colegio de Postgraduados

Martínez-Yrizar A, Sarukhan J, Pérez A, Rincon E, Maass J, SolisMagallanes A, Cervantes L (1992) Above-ground phytomass of a tropical deciduous forest on the coast of Jalisco, Mexico. J Trop Ecol 8:87-96

Méndez J, Santos A, Nájera J, González V (2006) Modelos para estimar volumen y biomasa de árboles individuales de Prosopis glandulosa, var. Torreyana en el ejido Jesús González Ortega No.1, Mpio. de Mexicali, B.C. Agrofaz 6:225-239

Méndez J, Luckie L, Capó M, Nájera J (2011) Ecuaciones alométricas y estimación de incrementos en biomasa aérea y carbono en una plantación mixta de Pinus devoniana Lindl. y P. pseudostrobus Lindl., en Guanajuato, México. Agrosciencia 45:479-491

Méndez J, Turlan O, Ríos J, Nájera J (2012) Ecuaciones alométricas para estimar biomasa aérea de Prosopis laevigata (Humb. \&Bonpl. exWilld.) M.C. Johnst. Rev Mex Cien For 3:57-72

Mendoza A, Galicia L (2010) Aboveground and belowground biomass and carbon pools in highland temperate forest landscape in Central Mexico. For 83:497-506

Meraz J, Rojas-García F, Galarza J, Torres J, Luna J, Ponce A, Romo J (2013) Utilización de ecuaciones alométricas para la estimación de biomasa y carbono en huertos de guayabo. IV Congreso Mexicano de Ecología. Villahermosa, México 18-22 marzo 2013

Monroy C, Návar J (2004) Ecuaciones de aditividad para estimar componentes de biomasa de Hevea brasiliensis Muell. Arg., en Veracruz, México. Madera Bosques 10:29-43

Montes de Oca E, García P, Nájera J, Méndez J (2009) Ajuste de ecuaciones de biomasa para Pinus durangensis (Martínez M.) en la región de El Salto, Durango. Rev Chapingo Ser Cienc For Am 15: 65-71

Mora E (2010) Carbono almacenado en la fitomasa aérea en una plantación de Pinus greggii Engelm. en Arteaga, Coahuila. Thesis, Universidad Autónoma Agraria Antonio Narro

Morgan WB, Moss PA (1985) Biomass energy and urbanization: commercial factors in the production and use of biomass fuels in tropical Africa. Biomass Bioenergy 6:285-299

Návar J (2009a) Biomass component equations for Latin American species and groups of species. Ann For Sci 66:208-216

Návar J (2009b) Allometric equations and expansion factors for tropical dry forest trees of eastern Sinaloa, Mexico. Trop Subtrop Agroecosyt 10:45-52

Návar J (2009c) Allometric equations for tree species and carbon stocks for forests of northwestern Mexico. For Ecol Manag 257:427-434

Návar J (2010a) Alometría para biomasa en especies arbóreas del noroeste de México. Trop Subtrop Agroecosyt 12:507-519

Návar J (2010b) Measurement and assessment methods of forest aboveground biomass: a literature review and the challenges ahead. In Momba M, Bux F (eds) Biomass, Sciyo, Croatia. Downloaded from SCIYO.COM. ISBN 978-953-307-113-8

Návar J, Nájera J, Jurado E (2001) Preliminary estimates of biomass growth in the Tamaulipan thornscrub in north-eastern Mexico. J Arid Environ 47:281-290

Návar J, Méndez E, Nájera A, Graciano J, Dale V, Parresol B (2004a) Biomass equations for shrub species of Tamaulipas thornscrub of northeastern Mexico. J Arid Environ 59:657-674

Návar J, González N, Graciano J, Dale V, Parresol B (2004b) Additive biomass equations for pine species of forest plantations of Durango, Mexico. Madera Bosques 10:17-28

Návar J, Ríos-Saucedo JJ, Pérez-Verdín G, Rodríguez-Flores FJ, Domínguez-Calleros PA (2013) Regional aboveground biomass equations for North American arid and semi-arid forests. J Arid Environ 97:127-135 
Oldeman RAA (1990) Forests: elements of silvology. Springer, Berlin

Pacheco G (2011) Ecuaciones alométricas para estimar biomasa aérea por compartimentos en reforestaciones de Pinus patula Schl. et Cham., en Xiacuí, Ixtlan, Oaxaca. Thesis, Universidad de la Sierra Juárez

Pacheco F, Aldrete A, Gómez A, Fierros A, Cetina V, Vaquera H (2007) Almacenamiento de carbono en la biomasa aérea de una plantación joven de Pinus greggii Engelm. Rev Fitotec Mex 30:251-254

Palma A (2011) Estimación de biomasa y carbono de Pinus pseudostrobus en San José del Rincón, Estado de México. Thesis, Universidad Nacional Autónoma de México

Pastor J, Bockheim JG (1981) Biomass and production of an aspenmixed hardwood-spodosol ecosystem in northern Wisconsin. Can J For Res 11:132-138

Pimienta D, Domínguez G, Aguirre O, Hernández F, Jiménez J (2007) Estimación de biomasa y contenido de carbono de Pinus cooperi Blanco, en Pueblo Nuevo, Durango. Madera Bosque 13:35-46

Rodríguez V (2013) Estimación dasométrica de carbono almacenado en un bosque de Abies religiosa (H.B.K.) Schl. Et Cham. del paraje El Cedral del Parque Nacional El Chico Hidalgo. Thesis, Universidad Nacional Autónoma de México

Rodríguez R, Jiménez J, Aguirre O, Treviño E (2006) Estimación de carbono almacenado en un bosque de niebla en Tamaulipas, México. Ciencia-UANL 9: 179-187

Rodríguez R, Jímenez J, Aguirre O, Jurado E (2007) Ecuaciones alométricas para estimar biomasa aérea en especies de encino y pino en Iturbide, N.L. Rev Cien For Mex 32:39-56

Rodríguez R, Jiménez J, Meza J, Aguirre O, Razo R (2008) Carbono contenido en un bosque tropical subcaducifolio en la reserva de la biosfera el cielo, Tamaulipas, México. Rev Latinoam Rec Nat 4: 215-222

Rodríguez R, Jiménez J, Aguirre O, Treviño E, Razo R (2009) Estimación de carbono almacenado en el bosque de pino-encino en la Reserva de la Biosfera el Cielo, Tamaulipas, México. Ra Ximhai 5:317-327

Rodríguez G, de Los SH, González V, Aldrete A, Gómez A, Fierros A (2012) Modelos de biomasa aérea y foliar en una plantación de pino de rápido crecimiento en Oaxaca. Madera Bosques 18:25-41

Rojo G, Jasso J, Vargas J, Palma D, Velázquez A (2005) Biomasa aérea en plantaciones comerciales de hule (Hevea brasiliensis Müll. Arg.) en el estado de Oaxaca, México. Agrociencia 39: 449-456

Rosenbaum KL, Schoene D, Mekouar A (2004) Climate change and the forest sector. Possible national and subnational legislation. In FAO forestry paper, vol. 144. Rome
Rykiel EJ (1996) Testing ecological models: the meaning of validation. Ecol Model 90:229-244

Segura M, Kanninen M (2005) Allometric models for tree volume and total aboveground biomass in a tropical humid forest in Costa Rica. Biotropica 37:2-8

The Plant List (2010) The Plant List. A working list of all plant species Version 1. http://www.theplantlist.org/

Tomas C (2013) Estimación de biomasa y carbono medinte ecuaciones alometricas en Quercus laurina Humb. y Quercus rugosa Née en predios bajo manejo del ejido San Pablo Ixayoc, Estado de México. Thesis, Universidad Autónoma Chapingo

Toribio M (2006) Almacenamiento de carbono en raíces de plantaciones de Eucalyptus grandis Hill ex maiden y Eucalyptus urophylla S. T. Blake en Oaxaca, México. Thesis, Universidad Autónoma Chapingo

UNFCCC, United Nations Framework Convention on Climate Change (2008) Report of the Conference of the Parties on its thirteenth session, held in Bali from 3 to 15 December 2007.Addendum, Part 2. Document FCCC/CP/2007/6/Add.1. UNFCCC, Bonn, Germany

Urquiza-Haas T, Dolman PM, Peres CA (2007) Regional scale variation in forest structure and biomass in the Yucatan Peninsula, Mexico: effects of forest disturbance. For Ecol Manag 247:80-90

Vigil N (2010) Estimación de biomasa y contenido de carbono en Cupressus lindleyi Klotzsch ex Endl. en el campo forestal experimental Las Cruces, Texcoco, México. Thesis, Universidad Autónoma Chapingo

Wang H, Hall CAS, Scatena FN, Fetcher N, Wu W (2003) Modeling the spatial and temporal variability in climate and primary productivity across the Luquillo mountains, Puerto Rico. For Ecol Manag 179: 69-94

West GB, Brown JH, Enquist BJ (1999) A general model for the structure and allometry of plant vascular system. Nature 400:664-667

Wirth C, Schumacher J, Schulze ED (2003) Generic biomass functions for Norway spruce in central Europe - a meta-analysis approach toward prediction and uncertainty estimation. Tree Physiol 24: 121-139

Zianis D, Mencuccini M (2004) On simplifying allometric analyses of forest biomass. For Ecol Manag 187:311-332

Zianis D, Mukkonen P, Mäkipää R, Mencuccini M (2005) Biomass and stem volume equations for tree species in Europe. Silva Fennica Monographs 4 